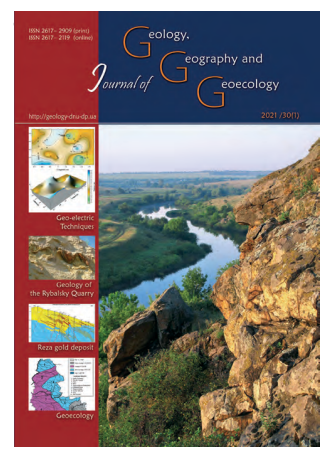

Journal of Geology. Geography and Geoecology

Journal home page: geology-dnu-dp.ua
ISSN 2617-2909 (print)

ISSN 2617-2119 (online)

Journ.Geol.Geograph. Geology, 30(1), 100-121. doi: $10.15421 / 112110$

V. V. Manyuk

Journ. Geol. Geograph. Geoecology, 30(1), 100-121.

\title{
New data on geology of the Rybalsky Quarry, unique object of geological heritage of Global Significance
}

\author{
Volodymyr V. Manyuk \\ Oles Honchar Dnipro National University,Dnipro,Ukraine,vgeoman@gmail.com
}

Received: 29.10.2020

Received in revised form: 21.11 .2020

Accepted: 08.12.2020

\begin{abstract}
Among the great variety of geological relics of Ukraine, one of the most attractive is the Rybalsky Quarry, located in the city of Dnipro, and well known outside Ukraine. First of all, it is famous for the Mandrykivski Layers exposed in one of the ridges of the Quarry back in the 1970s, although there are many other important peculiarities of the geological structure of the Quarry which attract scientists from Ukraine, Germany, France,
\end{abstract} Netherlands, Russia and other countries. There are full data on the history of discovery and survey of the Mandrykivski Layers from their discovery by Valerian Domger in 1882 to current studies that reveal various aspects of geological structure of the Quarry, the results of study of different groups of fossil fauna, compare them with the fauna of the Paris Upper Eocene basin and other wellknown locations. Particularly in the Rybalsky Quarry, thanks to the author's efforts, the Layers received the status of "layers with geographic name", as confirmed by the decision of Cenozoic Commission of the National Stratigraphic Committee of Ukraine in 2001. New fragments of the section of subaerial and subaqueous deposits of the Quaternary deposits were found and their composition, structure and complete stratigraphic content were studied. The research allows us to consider it typical for the Middle Prydniprovia. Fluvioglacial and lake-glacial deposits of the Dnipro glaciations in the Quarry exposed for the second time in 25 years, but this is the first time when their genetic origin, position in the section and lithological-facies peculiarities were determined. Thick layer of sands embedded on the roof of the Mandrykivski Layers were identified to the fifth or Hadzhybeiska terrace of the Dnipro, in the upper part of which there were notable siliceous-clayey-ferruginous formations or lateral crust (ferruginous crusts). The studies of the layer of brown-green and red-brown clays in the roof of the Mandrykivski layers allows us to presume their marine origin. In this case, they are underwater weathering crust (terra rossa) developed in the process of halmyrolysis or are the product of dissolution of carbonate silt enriched with detritus of mollusks, corals and other inhabitants of the warm Mandrykivske Sea.

Key words: Rybalsky Quarry, Mandrykivski Layers, climatolite, loess, fossil soil, geosite, crust

\section{Нові дані до геології Рибальського кар'єру - унікального об’скту геологічної спадщини Світового значення}

\author{
В.В. Манюк
}

Дніпровський національний університет імені Олеся Гончара, Дніпро, Україна,vgeотап@gтаil.com

Анотація. Серед великої кількості геологічних пам'яток України одним з найбільш привабливих залишається Рибальський кар'єр, розташований у місті Дніпро та добре відомий далеко за межами України. Перш за все завдяки мандриківським верствам, розкритих одним із уступів кар'єру ще у 70-х роках минулого століття, але, як з'ясувалося пізніше ще й чимало інших важливих особливостей геологічної будови кар'єру приваблюють дослідників з України, Німеччини, Франції, Нідерландів, Росії та інших країн. Наведено досить вичерпні дані стосовно історії відкриття і дослідження мандриківських верств від моменту їх відкриття Валеріаном Домгером у 1882 році до сучасних робіт, у яких висвітлюються різні аспекти геологічної будови кар'єру, результати вивчення різних груп викопної фауни, співставлення її з фауною Паризького верхньоеоценового басейну та з іншими відомими місцезнаходженнями. Саме в Рибальському кар'єрі, за клопотанням автора, верстви отримали статус «верств із географічною назвою», що підтверджено рішенням комісії кайнозою Національного стратиграфічного комітету України у 2001 році. Виявлено та досліджено нові фрагменти розрізу субаеральних і субаквальних відкладів четвертинних відкладів, їх склад, будову і повну стратиграфічну наповненість, що дозволило вважати його типовим для Середнього Придніпров'я. У кар'єрі, вдруге за останні 25 років розкрито флювіогляціальні і озерно-льодовикові відклади часів дніпровського зледеніння, але вперше встановлено їх генетичну приналежність, положення у розрізі та літологофаціальні особливості. Доведено приналежність потужної товщі пісків, залягаючих у покрівлі мандриківських верств до 
п’ятої або хаджибейської тераси р. Дніпра, у верхній частині якої виразно проявилися кремній-глинисто-залізисті утворення або латеритна кіраса (феррікрети). Дослідження товщі буро-зелених і червоно-бурих глин у покрівлі мандриківсьих верств, дозоляє припустити їх морське походження. У такому разі вони являють собою підводну кору звітрювання (терра роса), утворену в процесі гальміролізу, або продукт розчинення карбонатного мулу, збагаченого детритом молюсків, коралів та інших мешканців теплого мандриківського моря.

Ключові слова: Рибальський кар'єр, мандриківські верстви, кліматоліт, лес, викопний трунт, геосайт, кіраса

\section{Introduction.}

The geological history of the territory of Ukraine is characterized by incredible diversity and contains almost the entire range of the stratigraphic scale Precambrian to Holocene. Geodiversity creates respectively a large list of mineral deposits which are successfully extracted using various technical means. One of such methods is quarry, when not only ore rocks are extracted, but the landscape is damaged, causing ecological problems. At the same time, quarries are a great source of information about the geological structure of the fragments of the Earth's crust inaccessible from the surface, their mineral and natural diversities, tectonics, etc. One of such quarries is the Rybalsky Quarry, located within the city of Dnipro and well-known outside Ukraine. The Quarry became famous in Europe because of the discovery of unique Upper-Eocene fossil faunas in the Mandrykivski layers. According to the diversity and stratigraphic value of the Paleogene, scientists consider that the Mandrykivska Fauna is inferior only to the Paris Basin. This, however, is not the Rybalsky Quarry`s only special attraction or highlight. Over the long period of extraction of granites in the Quarry, numerous evidence of geodiversity there has been found, which is analyzed in this paper.

\section{Brief historical review.}

The objective of this research was not the analysis of all the literature sources in one way or another related to the discovery and study of the Mandrykivska fossil fauna. Among a large circle of scientists related to this event, we have to mention the first and the most famous ones on one hand and the ones responsible for discovery of the Mandrykivski Layers in the Rybalsky Quarry on the other hand. And by the way not only the people related to the Mandrykivska Fauna itself, first found in the Quarry in 1977, but also the ones who discovered other peculiarities of geological structure of this part of the territory of the eastern slope of the Ukrainian Shield over the period of 40 years. The Layers with their unique fauna were first discovered by Valerian Domger in 1882 in the River Dnipro during drilling of borehole for the construction of the Katerynoslavsky Bridge (Sokolov,1894, 1905; Domger,1902). There were remains of fish, numerous shells of mollusks, spicules of sponges, fragments of corrals, Bryozoa, nummulites, etc. Preliminary analysis of diverse fossil fauna from glauconite sands allowed V. A. Domger to come to the conclusion that the layers which contain it, according to the deposition, correspond to Middle-Eocene, the so-called "coarse limestone" of the Paris Basin. It has to be noted that despite the fact that Rybalsky Quarry is near $(4 \mathrm{~km})$ the location, the lithological-facies conditions of formation of the deposits, in which the fauna of Eocene basin lived, significantly differed from those which are typical for the Quarry. This indeed explains the impoverishment of the forms determined by V. Domger in the area of the Monastyrsky Island compared with the later found localities where the fauna-containing rock was mostly detritus, poorly cemented by a small amount of sandy-clayey carbonaceous material.

Somewhat later, in 1886, during the digging of a well in the manor house of a German, A. A. Osvald, in Mandrykivska Sloboda (currently city Dnipro), a layer of sand oversaturated with very well preserved shells was discovered. A professor of Kharkiv University A. V. Hurov, to whom A. A. Osvald gave the collection in the same year, identified the Mandrykivski sands to the Eocene and considered its synchronous sands and sandstones those of Traktemyrivka and Buchak villages. In 1894, M. O. Sokolov, as allowed by A. A. Osvald, made a vertical trial pit in the yard of his manor house, obtained a sufficient amount of fossils and based on their identification he drew a conclusion that the age of detritus sands of the Mandrykivka is of the Low-Oligocene, corresponding to the period of accumulation of the Latdorf Stage in Germany. He thought that the closest to the Mandrykivski glauconite sands are those around Latdorf, Unseburg, Osterweddingen and other territories then described by Adolf von Könen. Later the fauna of the Mandrykivska Layer was surveyed by A. V. Faas (1894), P. A. Tutkovsky (1895), L. L. Ivanov (1914), V. S. Slodkevych (1933), who proved that the detritus sands of Mandrykivka village, the Monastyrsky island and the area near the railroad bridge of stations Merefa-Kherson are an integral stratigraphic layer. In 1931 B. F. Meffert studied the foraminiferans fauna from the Mandrykivski detritus rocks and stated that 
most species were found to be of the Eocene age. He draws attention to a large amount of Nummulites and Discocyclina and underlines their absence in the Oligocene. In 1939 L.F. Lungershausen for the first time proposed that the Mandrykivski Layers are shallow water facies of the Upper part of the Kyiv stage. Later this presumption was confirmed by numerous works by O. K. Kaptarenko-Chornousova on Foraminifera (Kaptarenko-Cheronousova, 1941, 1946, 1949).

In 1947 the Mandrykivski Layers in the area formerly owned by A. Osvald was studied by M. N. Kliushnikov. He came to a conclusion that the area of distribution of detritus lime-clayey sands with fossils on the outskirts of Dnipropetrovsk expands far beyond Mandrykivka village and provided in-detail data on new locations. A significant achievement in studying the Mandrykivka fauna was the study by N. N. Karlov, the results of which were reported in 1950. He was the first person after V. O. Domger who collected and analyzed the rich paleontological deposits from the Dnipro River near Shevchenko Park, but this time in the northern-western part of the Monastyrsky Island during the construction of foot- and automobile bridge. Interestingly enough, N. N. Karlov for the first time mentioned the diverse fossil fauna discovered in the core sample the borehole drilled during the exploration within the future Rybalsky Quarry (Karlov, 1950). The author compares the Layers with the lightgreen sands embedded on the Kyiv marl.

In 1954 M. V. Yartseva provided persuasive data on the Upper Eocene age of not only the known locations of the Mandrykivska fauna, but other places, significantly distant from them. A notable event in the history of studying the age of the layers was the identification of the Latdorf Sands in Germany to the Upper Eocene, based on studies by Krutzsch and Lotsch (Krutzsch \& Lotsch, 1957). Complex study of deposits of the Mandrykivska fauna within Dnipropetrovsk was carried out by P. H. Nestereko, who provided the results in the book "Paleogenic sediments of the South European part of the USSR" in 1960 (Nesterenko, 1960), based on the analysis of a large amount of archive material (16 special borehole were drilled according to the profile which cross-sectioned the Dnipro in the area of Monastyrsky Island and included Mandrykivka village). M. V. Yartseva determined the complexes of nummulites from the core samples taken from the boreholes, the content of which allowed her to identify the deposits which contained them to the Upper Eocene (Jarceva, 1960). This is also confirmed by the content of mollusks extracted from the core samples from the borehols and identified by D. Y. Makarenko.
A new stage in studying the Mandrykivski Layers began with their exposure in the large area of the Rybalsky Quarry of extraction of granites for rubble and crushed stone. The Rybalske deposit of Precambrian crystalline rocks was for the first time explored in 1932. In the same year, the reserves of the natural stone for construction were approved in the amount of 4,029 thou $\mathrm{m}^{3}$, followed by mining operation of the deposits. Later, in 1956, a geosurvey of the Quarry was performed by Filippeo and in 1962 by Baranov A. V. for the purpose of increasing the reserves. The year when the section of Paleogenic deposits was exposed in the Quarry is unknown, but the first visits to the Quarry in order to carry out scientific studies took place in 1977. The fauna of the Mandrykivska Layers in one of the ridges of the Quarry in its southeast part was first described in 1978 by paleontologists of the Scientific-Research Institute of Geology of the Dnipropetrovsk State University, including M. F. Nosovsky, I. D. Konenkova. I. M. Barg and Y. M. Bohdanovych (Nosovskyi, Konenkova, Barg, Bogdanovich, 1978). A large complex of nanoplakton was discovered, identical to the one E. Martini identified in 1970 studying the samples of the Mandrykivski Layers (Martini, 1970), and which corresponded to zone NP19. The composition of mollusks was also studied, revealing the presence of single and colonial corals, Ostracoda, small nummulites, Bryozoa, shark teeth. Apart from the Chaplynsky Quarry (mistaken name of the Rybalsky Quarry), the paper presents paleontological characteristic of some other deposits of the Mandrykivska Fauna located within Dnipropetrovsk, or currently Dnipro. These are bore holes bored in the territory of the Karl Liebknecht Plant and the Peremoha housing complex, the material from core samples of which, similarly to the collection of fossil fauna, has not been preserved. Therefore, the only outcrop of the Mandrykivska Layers has been and still is the Rybalsky Quarry.

In the same year 1977 and during the following years, the issue of stratigraphy and paleontology of the Mandrykivski Layers in the Rybalsky Quarry was researched by the scientists of the Dnipropetrovsk Mining Institute (currently National Technical University Politechnika). The problem of identification of the age of the Mandrykivska Fauna was studied by Veselov A. O., Shyrokov A. Z., Dyssa F. M. based on the research of material from the core samples from a specially drilled bore holes in Mandrykiva village and analysis of the literature sources and comparison to the Upper-Eocene Fauna from well-known deposits on Ukraine (Shirokov, Dyssa, 1972; Veselov, 1972; Veselov, Golev, Lyulieva, Savenko, Sheremeta, 1974; 
Chekunov, Veselov, Gilkman,1976). The results of the studies conducted by the authors in the Rybalsky Quarry were published in the reports of the Academy of Sciences of the USSR in 1986 and contributed to growth of interest in further study of the unique Mandrykivska Fauna (Shirokov, Veselov, Stefans'kij, Petrusha, 1986).

Gastropods of the Mandrykivski Layers of the Rybalsky Quarry have been thoroughly surveyed since 1977. The prominent Russian paleontologist O. V. Amitrov emphasized that the Mandrykivsky Complex attracts special attention not only because it exceeds all other well-known paleontological complexes in the richness and integrity of the fauna, but also because according to geographic position, the species composition and age, it is close to typical northern complexes (Latdorf, Tongrian, Chegan), and according to the composition of the families belongs to the intermediate type (Amitrov, 1986, 1987, 1996). Amitrov O. V. also considers that the Mandrykivski Layers are characteristic of faster spatial changes in the complexity, indicating that repeat collections in the old location and discoveries of new deposits with the same integrity may extend the lists of the Fauna. He found over 400 species of gastropods, belonging to 39 families (Amitrov, 1986).

V. L. Stefansky (since 1986) has been working on a monographic description of Bivalvia mollusks of the Mandrykivski Layers, taking into account the new rules of zoological nomenclature and systematics, for 35 years. His collection and analysis of one the best collections of mollusk fauna of Mandrykivka gave the author a reason to consider the Mollusca complex of the Rybalsky Quarry an etalon for Upper-Eocene deposits of the shallow water facies of the territory of Ukraine (Stefanskyi, 1987, 1992, 2013a,b, 2014, 2015a,b).

Berezovsky A. A., starting in 1990, has been systematically performing surveys on Paleogene Bivalvia within the Kryvy Rih iron ore basin and is one of the prominent paleontologists who are highly familiar with Bivalvia of the Mandrykivski Layers of the Rybalsky Quarry (Berezovsky, 2010, 2015). In 1994, based on his discovery of 14 species of Bivalvia mollusks in the deposits of the Inhulets Quarry, which he identified as Middle-Eocene ones, known in other regions of Europe only in the Upper Eocene deposits, he came to a conclusion that most mollusks of the Mandrykivski Layers of Ukraine and Latford Stage in Germany have appeared in the Lutetian (Berezovsky, 1994). Nanoplankton and dinoflagellates of the Mandrykivska Layers in the Rybalsky Quarry were studied by N. A. Savytska, who indicates the presence of a nanoplank- ton complex of Discoaster saipantnsis subzone and an impoverished complex of dinoflagellates of the zone of Rhombodinium porosum. She has also determined a complex of nanofossils of Isthmolithus recurves of the zone of Discoaster barbadiensis and complex of dinocysts of Charlesdowniea clathrate angulosa.

During our in-depth geological mapping of the Dnipro - Tomakivka interfluves, in the layers of the Paleogenic rocks, the presence of the Upper Eocene deposits was for the first time paleontologically substantiated, which became another evidence of the broadest distribution of Alma (Upper-Eocene) transgression compared with the Middle Eocene (Konenkova, Bogdanovich, Koralova, Manyuk, 1995; Manyuk, 1999). Earlier, the northern border of its distribution was indicated much further south of the water area of the Kahovka Water Reservoir. An important result of the paleontological surveys was designation of 4 complexes of microfauna, typical for the Alma and Obykhivka suites and the obvious similarity of one of them to the complex of the Mandrykivska Layers of the Rybalsky Quarry. Apart from foraminiferans, the complex contains mollusks, Ostracoda, Bryozoa, corals, Algae, spines of Echinoidea, and various nanoplankton. The conducted studies revealed that the Upper Eocene deposits in the area of conjunction of the Ukrainian Shield, Prychornomorska and Dnipro-Donetsk depressions have been developing under the influence of the warm-water Alma Basin, from where water with high content of silica inflows from the side of the Dnipro-Donetsk depression. This conclusion is confirmed by designation of four complexes of microorganisms, including the first and the second ones characterizing the Obukhivska Suite of northern Ukraine, and the third and the fourth - Alma Suite of northern Ukraine (Konenkova, Bogdanovich, Koralova, Manyuk, 1995).

Since 1998, the first articles concerning not only the Mandrykivski Layers of the Rybalsky Quarry, but also the Quarry's geodiversity were published, thus presenting the quarry as a promising geological monument of nature (geosites) of European significance (Manyuk, 1998, 1999a,б, 2001a). The Rybalsky Quarry is indicated as a complex geological relic of nature (geosite) and deserves to be accredited with the status of object of the Nature-Reserve Fund of Ukraine (NRF). It has to be emphasized that it is the only Europe's outcrop of the Mandrykivski Layers with unique Upper-Eocene fossil fauna, represented by various Bivalvia and Gastropoda mollusks, nummulites, foraminifera, ostracods, dinoflagellates, corals, Bryozoa, teeth of sharks, spines of Echinoidea (Manyuk, 2001a,b; 2002a,b,c,d; 2003a,b). 
Of great significance in paleontological study of the Mandrykivski Layers in the Rybalsky Quarry were the surveys by the scientists of the Leipzig University who in 2001 together with Barg I. M. and Manyuk V. V. visited the Quarry. The first article in which the survey data on sharks from the Paleogene deposits of Dnipropetrovsk were presented was published in 1985 by the German paleoichtyologist O. Iekel (Iekel, 1895). A. Muller and O. Rosenberg studied the oolites of Osteichthyes (over 40 forms) and substantiated the actual value of this group of fossil remains for solving the issues of Paleogene stratigraphy. According to the authors ' conclusions, most oolites of the complex are known from the layers of the Bartonian and Latdorf, and some were determined for the first time at this stratigraphic level (Ariidarum germanicus, Parascombrops martini, Sparidarum noetlingi) (Rozenberg, 2001; Müller, \& Rozenberg, 2002, 2003).

\section{The main material.}

During our study in the territory of the Dnipropetrovsk Sheet (M - 36 - XXXVI) GDP-200 (further geological appraisal of the area in the scale of $1: 200,000)$, there emerged a question of determining the stratigraphic position of the Mandrykivski Layers and their volume, determining their facies specifics and borders of the distribution, and most importantly, at last, 120 years after their discovery, giving them taxonomic range of "the layers with geographic name". When considering the application of V. V. Manyuk, the Cenozoic Commission of the National Stratigraphic Committee of Ukraine took into account that the Mandrykivski Layers are a shallow-water equivalent of the Obukhiv Suite, the distribution of which is limited by the Paleo-depressions of the northeast slope of the Ukrainian Shield. The deposits of the Mandrykivska fauna are distributed within the Vilnohirska, Borodaivska, Samotkanska, and Shatohynska, Troiitska and Myroliubivska Paleo-depressions. They are embedded with signs of erosions on coal-terrigenous formations of the Buchatska series or directly on the Precambrian rocks. They are overlapped by deposits of the Mezhyhirska suite or younger formations. The decision was made to approve "the Mandrykivski Layers" as a separate stratigraphic unit "layers with geographic name". As stratotype of the Mandrykivski Layers, the south-east slope of the Rybalsky Quarry was proposed, within which the layers outcropped at the distance of around $200 \mathrm{~m}$, having the thickness of to $3.2 \mathrm{~m}$ and the exploitation of the granites in this direction at the time was not planned (Manyuk, 2003b).

The structure of the fifth or the Zavadivsko-
Dniprovska above-floodplain terrace of the Dnipro, for the first time exposed by one of the ridges of the Quarry in 2002, is considered in detail. The structure of the Quaternary deposits in the Rybalsky Quarry, despite not being designated as having European significance, is extremely valuable for Ukraine. For the first time, the author drew attention to the specific section of the Quaternary Layer of the Quarry during the INQUA Conference in Ukraine in 2001 (Manyuk, 2001). In order to describe section 5 of the terrace, the history of the issue needs to be reviewed. In the abovementioned article by Shyrokova O. Z . et al (Schyrokov et al., 1986), the authors made an unexpected conclusion about the origin of the Mandrykivski layers, identifying them to fluvio-glacial deposits. Secondly, re-deposition of the fauna was indicated by Petrenko A. A. (Petrenko, 2003) based on questionable evidences which were disproved by the following researches (Barg, Manyuk, 2004). It is worth quoting the conclusion of $\mathrm{O}$. V. Amitrova, who writes "The persuasive argument against the views of Shyrokov and Dyssa is that in location the fauna is well preserved, including fauna extremely rare for the Middle and the Upper Eocene of Ukraine, and therefore there is a possibility that while retreating the glacier collected the material from several (at least two) unique locations of the fauna of different age and drove them dozens of kilometers, mixing and depositing them, not harming the integrity" (Amitrov, 1986). Bringing up this discussion is not an accident. The southern border of the thickest Dniprovsky (Riss) glaciations remained depicted on the maps unchanged for over 130 years, since S. M. Nikitin recognized it in the valley of the Dnipro at $48^{\circ} 42^{\prime} \mathrm{N}$, i.e. current Domotkan village. Therefore, during geological surveys in the territory further south from this latitude, the discovered deposits which looked like fluvioglacial were identified to river alluvium. Thus, the exposure of section 5 of the terrace with clear signs of fluvio-glacial currents in the lower part of the Dniprovsky loess in the area became a notable sensation (Manyuk, 2002a). At the same time, this was so unexpected that it remained unreported in the publications. Nonetheless, we shall return to this later.

An important constituent of geodiversity of the Quarry as a geologic monument is the ancient Precambrian basement, the peculiarities of which were for the first time described in 2002 (Manyuk, 2002a). According to these data, the oldest formations in the Quarry are crystalline rocks of the Dnipropetrovsk infra-crystalline ultra-metamorphic complex of Mesoarchean (Azovian) with absolute age of 3.4-3.2 B years. It is a complex conjunction of grey and light grey gneiss- 
oid granite and migmatites of mostly tonalite and tonalite and trondhjemite composition, dark grey (to black) dense massive or gneiss-like amphibole-biotite crystalline schists of average composition and dark massive or low schistose amphibolites with numerous veins of aplite and pegmatoid microcline granites, with interveins of tremolites, actinolitite, biotites. In the ledges of the Quarry and along them, one can see a complex evolution of the composition due to numerous folded deformations and multi-phase pattern of development of various components of the complex. There are broadly distributed palingenetic and injection-metasomatic migmatites with broad diversity of texture types and numerous relic fragments of supracrystal substrate. The large area of artificial outcrop and absence of weathering of rocks in the lower ridges of the Quarry allow monitoring the changes in the structures and textures of the rocks, pattern of boundary zones of the layers, and the processes of biotitization, chloritization, silicification and epidotization, determining the present systems of fractures and determining elements of their embedding (Manyuk, 2002a).

After A. Muller and O. Rosenberg, starting from 2004 the research on the Rybalsky Quarry`s oolites of Osteichthyes has been continued by M. I. Udovichenko and A. V. Bratishko. A complex of oolites of 29 species of Osteichthyes was distinguished, eight of which were unknown until then for this location. M. I. Udovichenko came to the conclusion that the glauconite sands of the railway bridge, studied by V. Domger, are older than the detritus clayey sands of the Rybalsky Quarry, and most likely correspond to the lower part of the Priabonian stage (Udovychenko, 2009, 2010; Bratishko, 2009) .

The studies of the German scientist Dirk Fehse in 2011 in the Mandrykivski Layers revealed a new species from the Cypraeoidea family - Eotrivia procera sp. Nov. In his work, Dirk Fehsa wrote: "In the following this species, new to science, is described as Eotrivia procera sp. Nov." (Fehse, 2011).

Peculiarities of the geological section of the Quaternary deposits in the Rybalsky Quarry are most accurately described in the article "Quaternary deposits in the Rybalsky Quarry of Dnipropetrovsk" published in 2014 (Manyuk, 2014).

\section{Results and analysis.}

Long monitoring of the peculiarities of geological structure of subaerial and subaqueous deposits of the Anthropogene Epoch in the ledges of the Quarry clearly demonstrates the great value, completeness, and at the same time, certain exceptionality of separate elements of the Quaternary section. The Middle-
Upper Pleistocene part of the section significantly exceeds the one exposed in the Sazhavtsi ravine, where the stratotype of the Kaidak fossil soil the section composed of Quaternary deposits is located (Manyuk, 2014). If in Stari Kodaky one can see only fragments of the section exposed by the lateral deep gullies and in the condition of overburden removal, one ledge of the Rybalsky Quarry represents a complete section of alternation of fossil soils and loess horizons - starting from present day chornozem to the Vytachivsky fossil soil, and another ridge located lower has a notable outcrop of a large fragment of the section ranging from Udaisky climatolite to the Zavadivsko-Dniprovska terrace, and in the north-west part of the Quarry, there is the remaining part of the section from the Tilihulsky horizon of the lower Pleistocene to the Kryzhanivsky Upper Eopleistocene inclusive. Without any exaggeration, we should state that the Rybalsky Quarry is the only place in Ukraine, where one can see an exceptionally full section of 19 horizons of the Quaternary system (the Kryzhanivsky climatolite to the present day soil) without any need of overburden removal. Even if the Quarry would have been worked-out, and not operating, the section of sedimentary rocks is destined to be ruined under the action of natural geological processes, unlike the crystalline Precambrian rocks. This obliges us to give primary characteristic of the accessible section, hoping to attract attention to it, involve the interested community in its thorough study using analytical researches as an important key section of the Quaternary system.

1. eH - Current soil. Soil-vegetative layer is represented by low-humus micelle-carbonate chernozem with poorly developed illuvial horizon $(0.3-0.8 \mathrm{~m})$. In most sections the soil has no structure, loose, almost always with the signs of technogenic mixing. Similarly to the area below, the embedded loams are different by coarser dispersive composition (to loamy sand) due to vicinity to the Dnipro.

2. vdPIIIpc - the Prychornomorsky horizon. The loam is brown-pale yellow, light, loess-like, microporous, limey, loose, with small amount of carbonate micelle, large aleurite structure (to loamy sand), with singular molehills, indistinct vertical prismatic structure. The boundary surface with the lower embedded soil is plain, distinct. The roof has signs of processing by the Holocene soil development. Thickness is up to $0.9 \mathrm{~m}$.

3. ePIIIdf - the Dofinivsky fossil soil. Loam is light greyish brown, light, macroporous, loose (to alleurite), calcareous, in the lower, illuvial, part is exposed to light, with thin coatings of carbonates and micelle, rarely hydroxides of manganese, with signs 

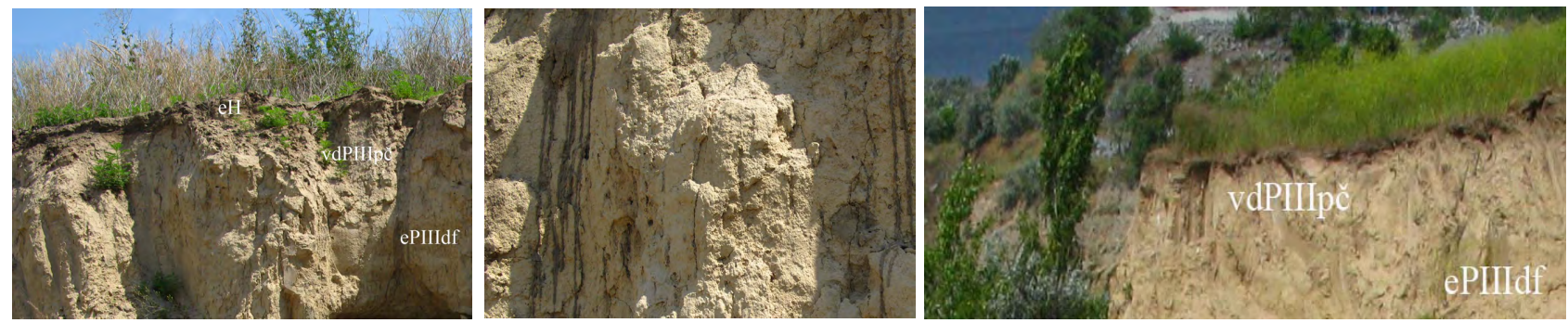

Fig. 1. The upper part of the section of the Quaternary deposits (Holocene, Prychornomorsky and Dofinivsky climatolites).

of gleyization. The lower boundary is uneven, with inflow pattern. Thickness equals $2.10 \mathrm{~m}$.

4. vdPIIIbz - the Buzky horizon. The clayey sand is light yellow-pale yellow loess, light, homogenous, significantly calcareous, macroporous, friable, large-aleurite, of prismatic structure with carbonate micelles. The lower boundary is distinct, even. Thickness is $1.6-3.0 \mathrm{~m}$. As we know, loess of the Buzky horizon in Ukraine in many sections contains interlayers and inclusions of volcanic ash, which is being attributed to the eruption of the Italian super volcano Phlegraean Fields 39 thousand years ago (Kosmachev,V.G., Kosmacheva, 2018). From this perspective, the Buzky loess, notably outcropped in the Quarry, definitely requires further study (Fig. 2). ticeable amount of fine-grained sand), homogenous, with wedge-shaped structure, significantly calcareous with carbonate pseudo micelles, with singular cryoturbate, with small carbonate concretions (up to 0.5 $\mathrm{cm}$ ), with point-like inclusions of manganese oxides. Thickness is $3.0-3.5 \mathrm{~m}$.

7. ePIIIpl ${ }_{2}$ - the Prylutsky fossil soil is represented by the suite composed of two soils. The upper soil is a grey to dark grey loam with brownish tone, averagely or just slightly consolidated, calcareous, fine-aleuritic, with prismatic structure, with indistinct lower boundary. The upper boundary is indistinct and uneven. The rock becomes lighter downward, obtaining brownish tone, gradually transferring to the lower layer. Thickness is $1.2 \mathrm{~m}$.



Fig. 2. The Buzky horizon in the southern part of the Rybalsky Quarry with increased fragment

5. ePIIIvt - the Vitachevsky fossil soil. The loam is brown with reddish tone, light, limey, finealeurite, prismatic structure, in the lower part with indistinct lightened illuvial horizon with carbonate efflorescences, small point-like carbonate inclusions $(0.2 \mathrm{~m})$. In the upper part of the layer, the soil is distinct by greater density and signs of ferruginization. The lower boundary is uneven, with inflow pattern. Thickness equals $1.3-1.8 \mathrm{~m}$ (Fig.2).

6. vdPIIIud - the Udaisky horizon. The loam is pale yellow-yellow, light, loess-like, macroporous, loose, composed of large-aleurite (to aleurite with no-
8. ePIIIpl The Prylutsky fossil soil. The lower subhorizon of the suite of soils. The loam is greybrownish-brown, calcareous, macroporous, of prismatic structure, homogenous, in some places in the lower part $(0.3 \mathrm{~m})$ transitions into carbonate white illuvium. The upper and especially the lower boundaries are uneven, indistinct. Thickness is $0.7 \mathrm{~m}$.

9. vd P III ts The Tiasminsky horizon. The loam is yellow and pale yellow to light pale yellow, light, loess-like, fine alleuritic, light, macroporous, of prismatic structure, highly calcareous, with small amount of carbonate pseudomicelle, and is homogenous in the 

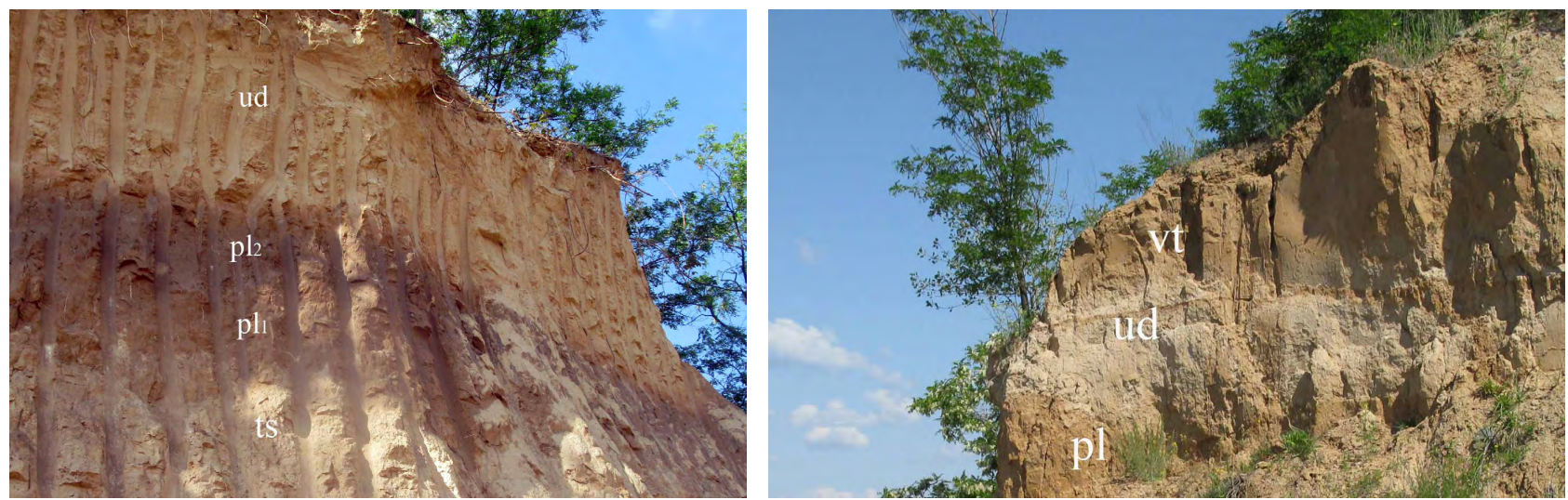

Fig. 3 The Udaisky and Prylutsky horizons in the sections of the Rybalsky Quarry

upper part. Thickness of the massive loam is up to 1.5 $\mathrm{m}$. Lower, the loam is different by presence of several interlayers of grey interstadial soil of $10-15 \mathrm{~cm}$. Its texture has coarse layers, with alternation of pale yellow-yellow loess-like loam of large aleurite structure (to fine-grained sand) of darker brownish-brown colour, closer to light one according to the structure. The loam is loose, friable. Thickness is $1 \mathrm{~m}$. In the northern-western part of the Quarry, in the lower part of the Tiasmynsky loess, in the regions of the vertical structure, there are well-developed dense carbonate formations of elongated form of $1-3 \mathrm{~cm}$ diameter. The rock in this section is looser, of shell-shaped structure. The upper boundary is uneven, gradual, with notable signs of influence of pedogenesis of the Prylutsky period, the lower boundary is distinct, even.
10. ePIIkd 2 The Kaidatsky fossil soil. The upper soil of the suite of the soil. It is loam of dark grey colour, chernozem-like (close to podzolized chernozem), swollen and insignificantly consolidated, largealleuritic, of prismatic structure, limey, homogenous, without any carbonate inclusions, with singular molehills filled with darker soil, with insignificant amount of dendrites of manganese oxides, with distinct and even upper boundary and gradual, tortuous lower one. Thickness is $1.1 \mathrm{~m}$ (Fig. 4).

11. ePIIkd ${ }_{2}$ The lower soil of the suite of the Kaidatski soils. The loam is dark grey brown, grey with brownish-brown tone, calcareous, macroporous, of prismatic structure, large-alleuritic, the lower part of the layer has well noticeable illuvial horizon with lightened area, more carbonate, with small point-like
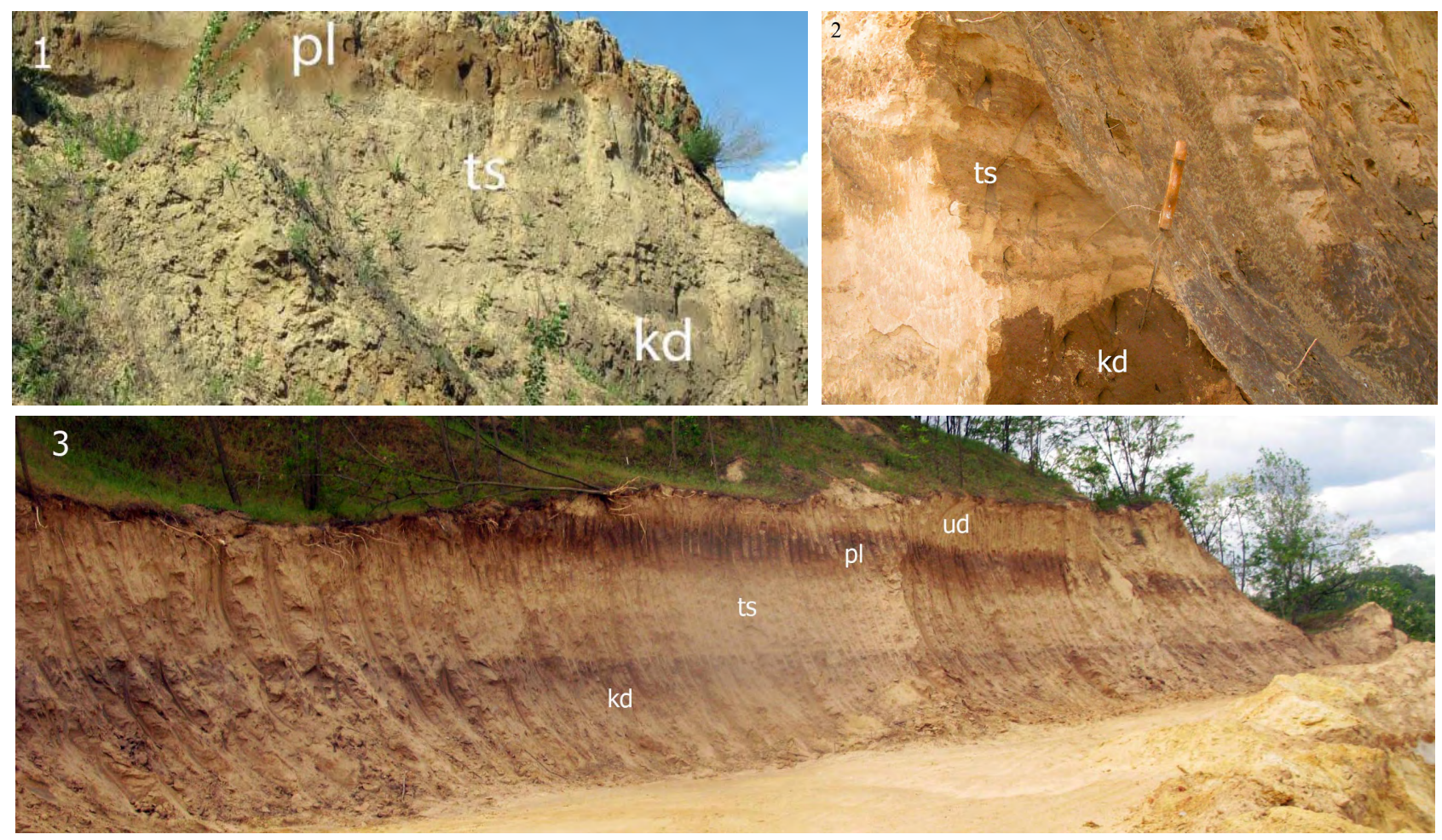

Fig. 4. The Tiasmynsky climatolite in the section of Quaternary deposits in the north (1) and south ( $2^{\text {nd }}$ fragment with interstade, 3 overall view) parts of the Quarry 
inclusions of carbonates and their pseudomicelles, less homogenous, denser. The lower boundary is distinct, uneven, with inflow pattern in some places. Thickness varies 1 to1.6 m. (Fig. 4).

Somewhat different is the profile of the Kaidatsky soil in north part of the Quarry, where it is lighter (grey), homogenous, consolidated and overlapped by contemporary soil (Fig. 5). The third type of the profile is exposed in small gully in the central part of the Quarry, and is dark grey chernozem-like loam, calcareous, homogenous, large-alleuritic (Fig. 4, 1). This section of this gully has in particular for over 20 years served as an excellent etalon section of the Middle-Upper Pleistocene subaerial deposits for practical education of Geology students and for scientific surveys. Unfortunately, it is now overgrown with trees, while the slopes need digging and clearing (Fig. 2).
12. vdPIIdn ${ }_{3}$ The Upper Dniprovsky stade. The loam is light-pale yellow-yellow, light, loess-like, highly calcareous, homogenous, in the upper part of the layer is dense, calcareous down to the lower part, fine-alleuritic, of wedge-shaped structure, with singular small swollen carbonate concretions $(2-5 \mathrm{~mm})$ and thin coatings of manganese oxides. Thickness of the layer is $3.5 \mathrm{~m}$. It should be noted that the shucksshaped mentioned above (the Dniprovsky, Tiasmynsky and others) are obviously typical loesses, and the name "loess-like loam" is retained exclusively based on its traditional use during the performance of geological surveys.

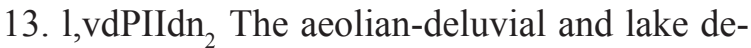
posits of the Middle-Dniprovsky stade. The loam is thin-layered, significantly calcareous, non-homogenous. It is a thin layer of greyish-yellow (to pale aleurite with light brownish tone, of coarse granulometric

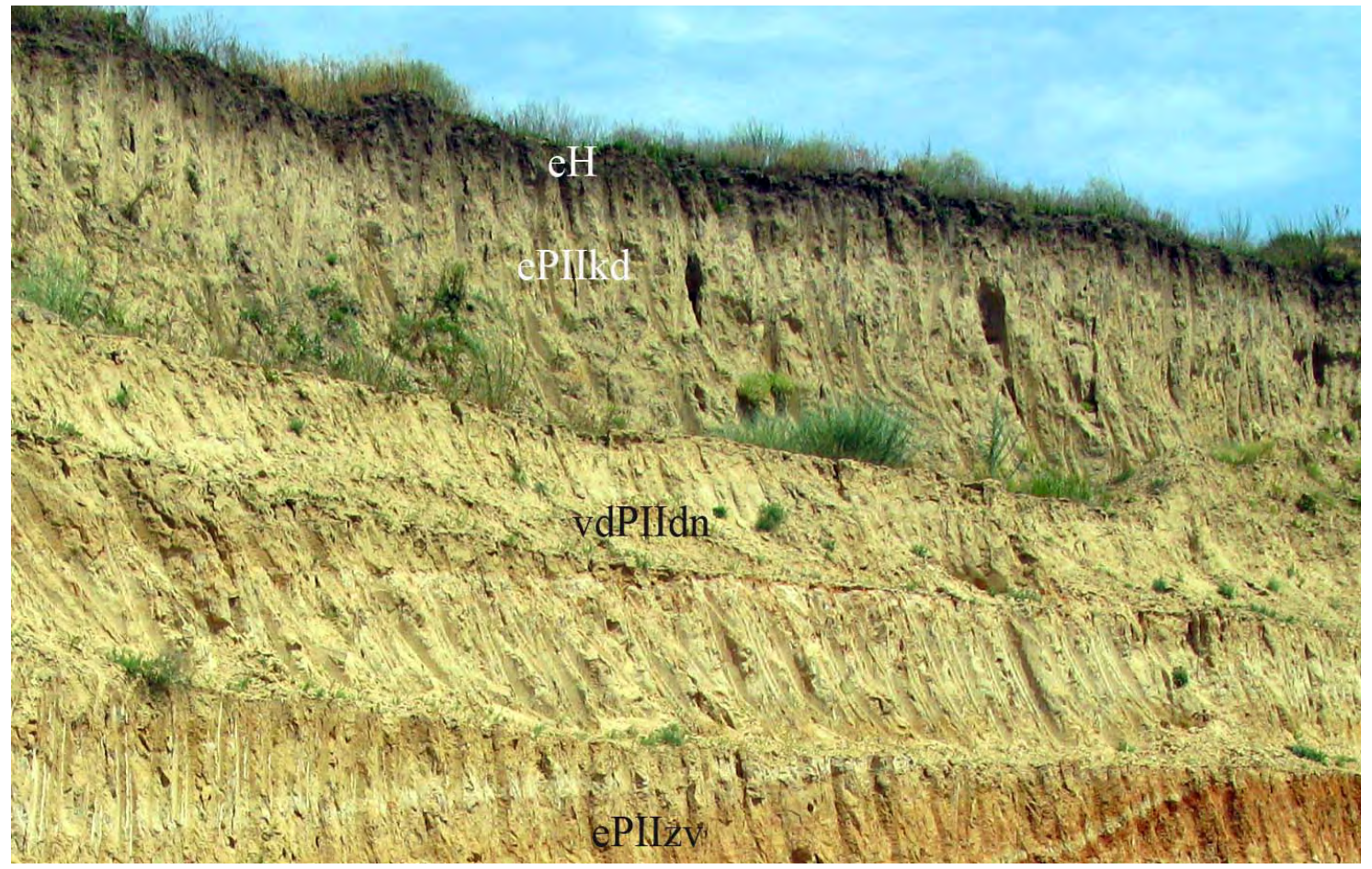

Fig. 5. Section of the Middle Pleistocene deposits in the north part of the Quarry (the Kodatsky and Zavadivsky fossil soils and the Dniprovsky loess)
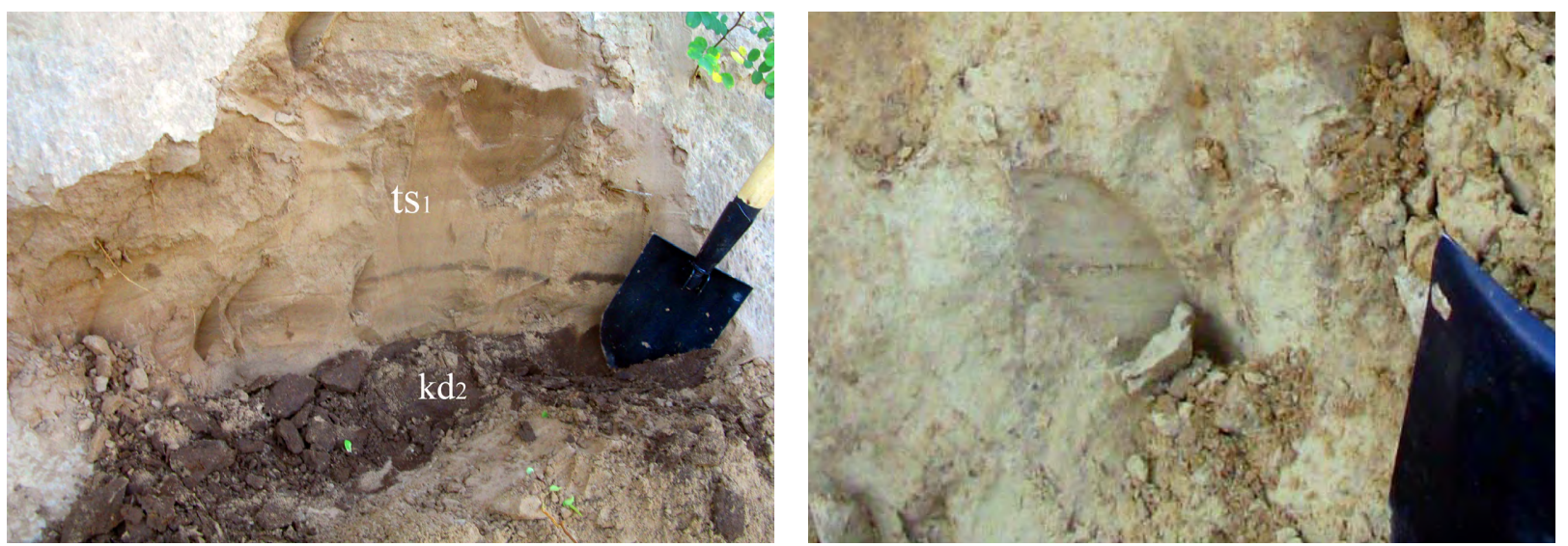

Fig. 6. The upper and lower boundary of the Kodatsky soil with loess horizons 



Fig. 7 Linear erosive processes in loess of the Dniprovsky horizon

content (to fine-grained quartzintic sand). Thickness of interlayers is irregular, varying several millimeters to $1 \mathrm{~cm}$, with uneven, often having wavy surfaces of overlapping. Thickness is $1.8 \mathrm{~m}$. Swollen, very soft, silty soil, very porous, easily erodible by even least water currents and on the surface of the Quarry's ridge is composed of the lake Dniprovsky loam, there are formed quite deep tortuous erosive washouts. It is another attraction of the Rybalsky Quarry, important for practical education of students (Fig. 7, 8).

14. fg,1 PIIdn 2 Fluvioglacial deposits of the lower stade of the Dniprovsky climatolite. Sand is quartziferous, ochre-yellow, non-homogenous, bright green and red, with signs of intense ferruginization in some places, overlaps with light yellow, poorly sorted, mostly fine-average grained, with interlayers of grey-

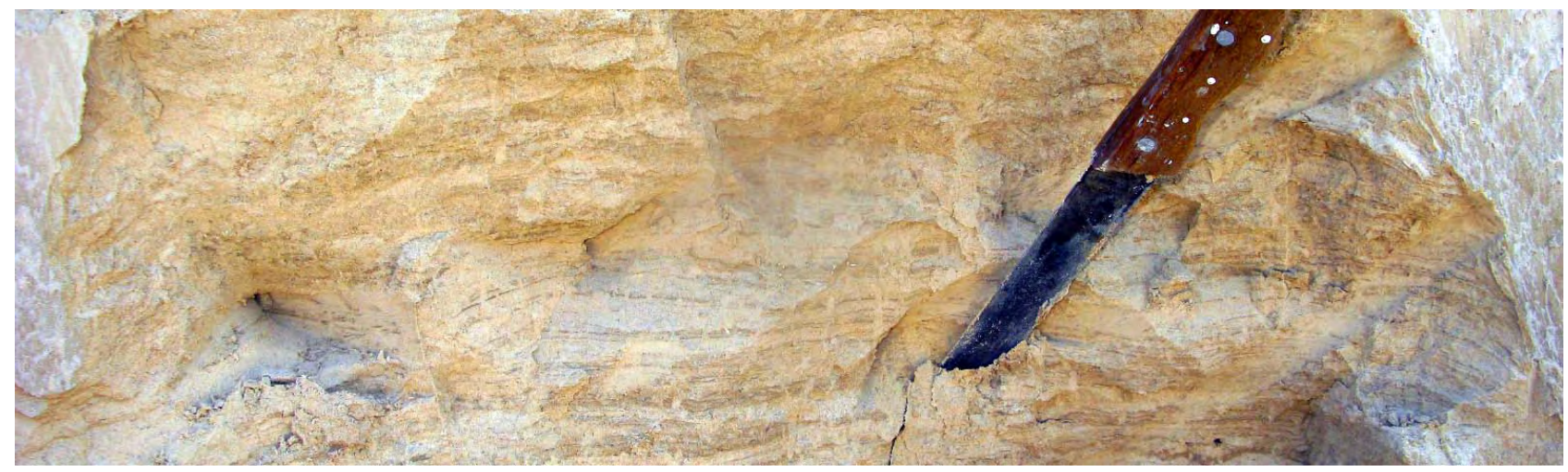

Fig. 8. Lake deposits of the Dniprovsky Age in the north-east part of the Quarry 

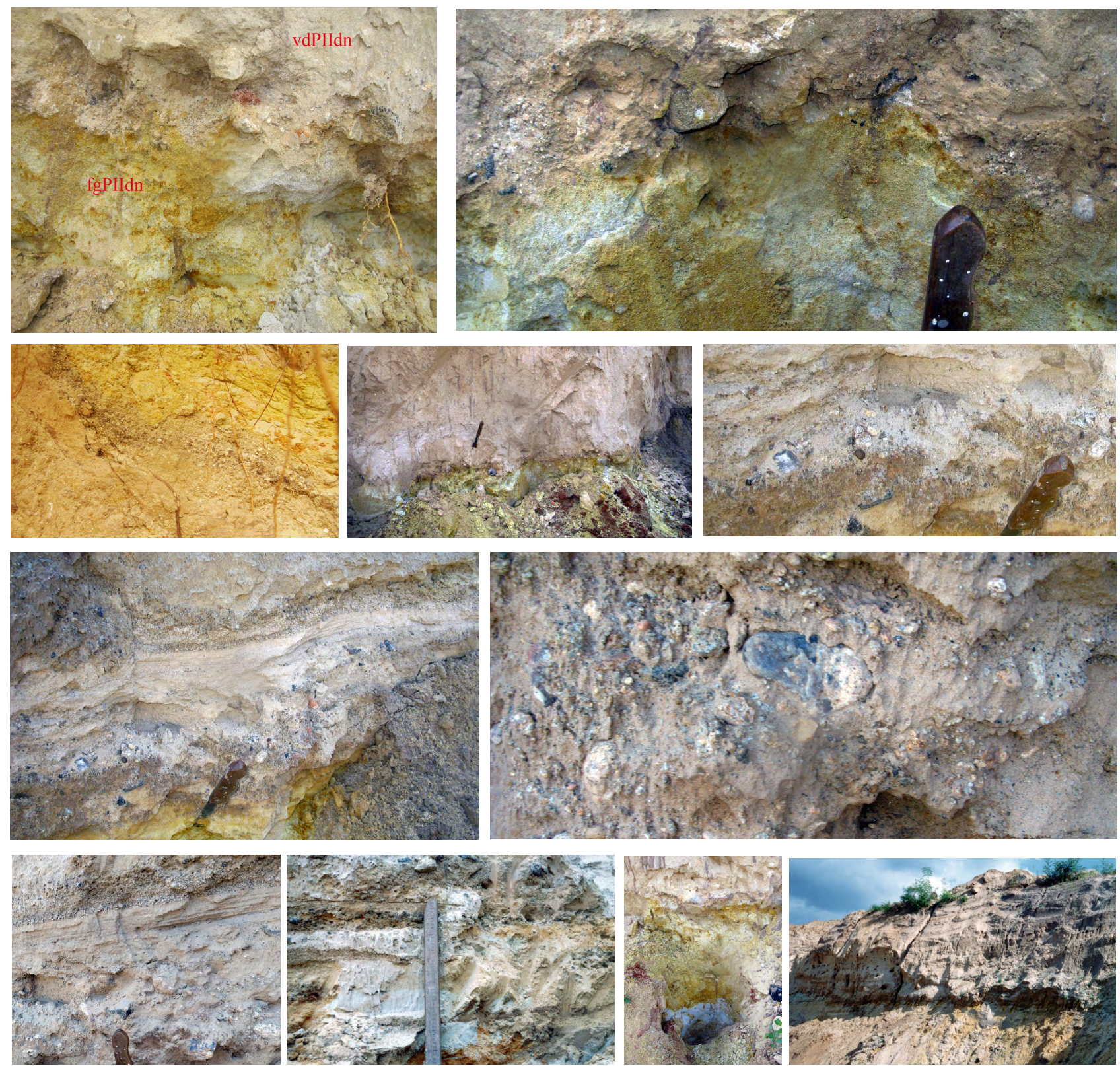

Fig. 9. Fragments of the section of the boundary zone of aeolian-deluvial and lake-glacial loams with fluvioglacial deposits.

yellow aleurite. In the upper part of the layer, the interlayers of fragmented non-sorted material from coarse sand and gravel to large-grained sand and even boulders, the size of which varies 10 to $20 \mathrm{~cm}$, rarely to $0.4-0.6 \mathrm{~m}$. Fragments, both rounded and angular, are different in shape and composition. These are granites of different composition and different colour, gneiss, migmatites, amphibolites, diabases, pegmatites, quartzites and vein quartz, often with epidote, sandstones of different colour, sometimes quartz-like, corrosive, with signs of alkalinization and ferruginization, gabbro, cataclise, diorites, etc. Thickness of separate layers is $3-5$ to $20 \mathrm{~cm}$. Sands embedded lower also contain a small amount of debris. The total thickness of the layer is 0.7 to $1.2 \mathrm{~m}$. For the first time such a section was exposed in the Rybalsky Quarry back in 2000, but the presence of typical fluvioglacial deposits on the latitude of Dnipropetrovsk was so unexpected that they were identified by the author of this article to large river alluvium (Manyk, 2001a). We mapped similar deposits much farther south, in Kobeliaky district (the Dnipro-Donets Rift), in a typical area of distribution of the Dniprovsky (Riss) glaciation. At the same time, previous articles contain no mentions of signs of fluvioglacial deposits south of the Borodaiivski eratic boulders. Now, there are more than enough evidences of presence of an outwash plain, and they are more than convincing (Fig. 9).

A question occurs whether the origin and interlayer of red-brownish (to red) clay is located lower in the section, under the layer of fluvioglacial gravel-crushed stone deposits. Directly underneath 
it, the section of the fifth (Zavadivsko-Dniprovska) terrace begins, having emerged at the beginning of the Zavadivsky period, which was before the Dniprovsky (Riss) glaciations. At the final stage of development of the alluvium of the terrace, the current in the river valley significantly slowed, creating conditions for accumulation of clayey material in the floodplain of the Dnipro, especially in the depressions and their periphery areas. As we know, the Zavadivsky fossil fauna is the first beneath the surface, which has distinct red colour, therefore it is no surprisethat it was driven away from the drainage divide which at the time was the arena of its accumulation. The deposits have no obvious signs of re-deposition and development in the complex dynamic conditions of the river valley.

The clay is bright red, dispersed coarse (to loam), limey, with particles of carbonate concretions and inclusions of non-sorted and non-rounded debris material (diorhytes, granites, quartz, sandstone) with dendrites of manganese oxides (Fig. 10).

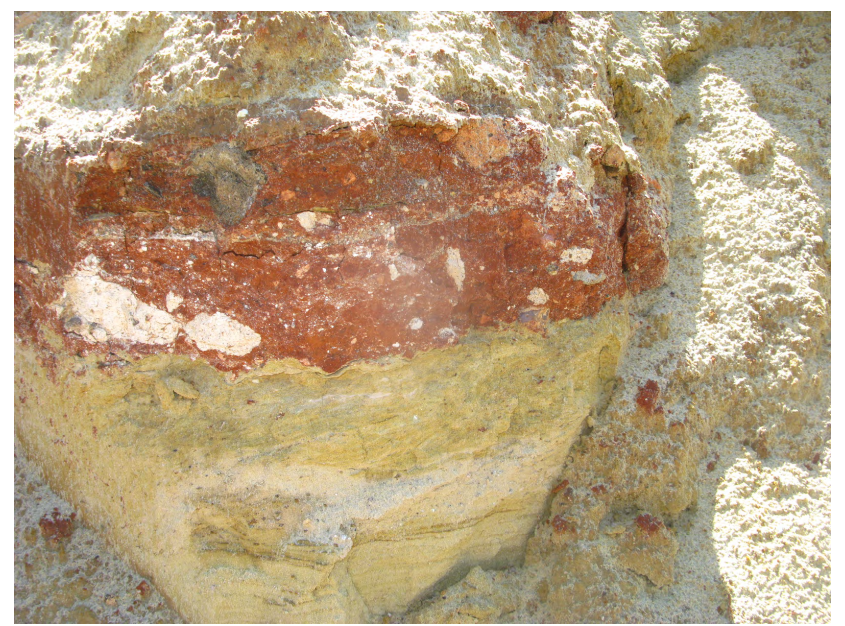

desquamation have created unusual, to some extent exotic morphological forms of Precambrian rocks. Therefore, the next attraction of the Quarry may be considered the giant boulders, "dressed in a shirt" of clayey weathering crust and surrounded by shells of weathered granites of various forms (Fig. 11). It has to be noted that on these exotic boulders, outside the range of distribution of the Mandrykivski layers, there are embedded brownish-green clays which overlap these layers and the lake genesis of which could not be considered undeniable. Nonetheless, we shall get back to them later.

16. $\mathrm{a}^{5} \mathrm{PII} \mathrm{zv}$-dn the Zavadivsko-Dniprovska (the fifth or the Hadzhybeiska) above-floodplain terrace. Sand is quartziferous, of yellowish-grey colour, with interlayers of grey, ochre-yellow and white, well sorted, fine- to average-grained, calcareous, in the lower part of the layer it is slightly clayey, more consolidated, of thin- and average lamination, with wavy-parallel texture in some places. The layer of sands of $12 \mathrm{~m}$



Fig. 10. Fragment of the layer of fluvioglacial deposits with interlayer of red-brownish clay and with low amount of non-rounded and non-sorted debris.

15. fg, 1 PIIdn ${ }_{1}$ Fluvioglacial and lake deposits of the Lower Dnipro stade. Sand is quartzitic, yellowgrey, fine-grained, calcareous, poorly sorted, nonhomogenous, slightly clayey in some places, with distinct horizontal, slightly wavy lamination, with a high amount of small debris material of the same composition and compound as clay (Fig. 10). The upper boundary is distinct and even, and in the foot the sand layer gradually transforms into alluvium of the terrace which was washed out during the Early Dnipro period.

At higher hypsometric level, this sand is embedded directly on crystalline basement, the rocks of which in this area of the Quarry underwent intensive weathering. The totality of quite specific physical-chemical processes of weathering, intensive thickness is distinctively divided into two parts. In the upper one, lighter more loose sands and friable sands with notable layering dominate, while in the lower one - darker (ochre-yellow) ones with only slightly noticeable lamination. The layer of sands exposed by the Quarry is bent in the central part of the section, and the layers are embedded toward the center at an angle of $7^{\circ}$ in the north (from the side of the Dnipro River) to $15^{\circ}$ in the south (Fig. 12).

The presence of a thick alluvial layer formed at the beginning of the Zavadivsky period and the relics of red-brown Zavadivsky fossil soil in the roof of the terrace well correlate with presumption of P. Gozhyk (2013) that this part of the section corresponds to the Lower Zavadivsky-Lyhvinsky interglacial period (Holstein) (Gozhik, 2013). 



Fig. 11. Consequences of physical-chemical weathering of crystalline rocks of the Precambrian basement in the form of disintegration, ferruginization, hydration reaction, dialysis, hydrolysis and desquamation

In the upper part of the terrace, in its roof, the lateritic kirasa (ferricrete ) formed most likely in the final stage of the development of the terrace alluvium, when the surface ceased to be flooded with water, and the siliceous-clayey-ferrugenous formations underwent oxidation and densification in the climatic conditions close to the tropical (Fig. 13).

Interestingly, we saw such formations in the upper part of the valley of the Psel River, in Shpyliv- ka village during the study of geological relics of Ukraine (Bezvynniy, Bobrov, Bryanskiy, Vashhenko, Volnenko, Manyuk, ... Shevtsova, 2011). There, siliceous-ferrugenous consolidated crusts are also embedded on the boundary of fluvioglacial layer of the Dniprovsky glacial and the layer of horizontally layered sand deposits of the Psel river terrace, indicating similar conditions of lithogenesis and diagenesis within these territories (Fig. 14).

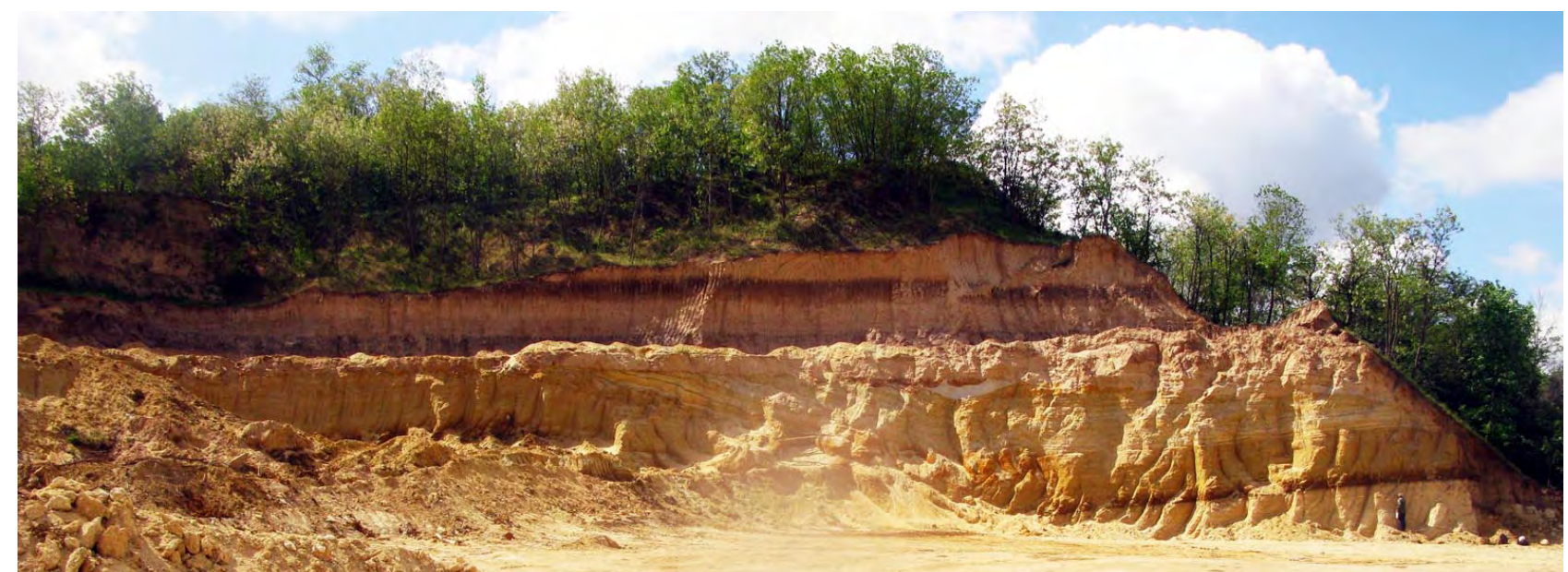

Fig. 12 Boundary of the layer of sands of the Hadzhybeiska terrace (the fifth) of the marine deposits of the Upper Eocene (Mandrykivski Layers) 

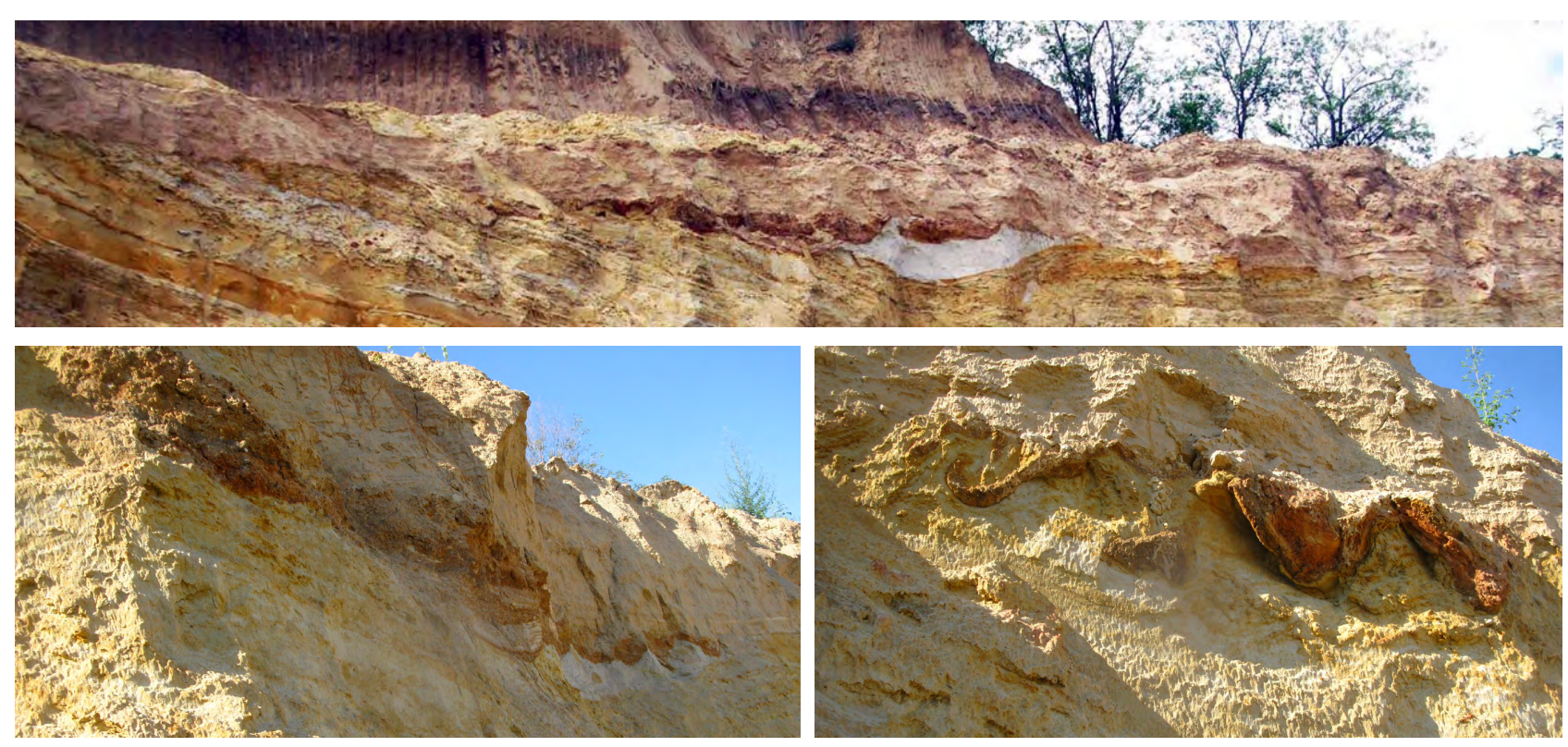

Fig. 13. Siliceous-clayey-ferrugenous ferricretes (lateritic crust - kuirass) at the boundary of fluvioglacial deposits with the alluvium of the fifth terrace.

In most of the literature sources it is considered that such solid crusts or duricrust (ferricretes, silcretes, calcretes) are characteristic exclusively for regions with tropical climate and the condition for their development is presence of a source (particularly iron oxides), its transportation (in our case capillary elevation from the sands of the Hadzhybeiska terrace) and deposition with subsequent diagenetic changes (GanDixon, 2009). This is confirmed by the lenses of quartzitic, white, fine-grained, well sorted sand below the cuirass horizon (Fig. 13). Iron oxides have been completely drifted out of the sand, unlike the ferruginized laminated sands, among which it is embedded.

The age and origin of the clays which are embedded on the foot of the fifth terrace and on the surface of the Mandrykivski Layers or the crystalline Precambrian rocks remains a subject of discussion and require
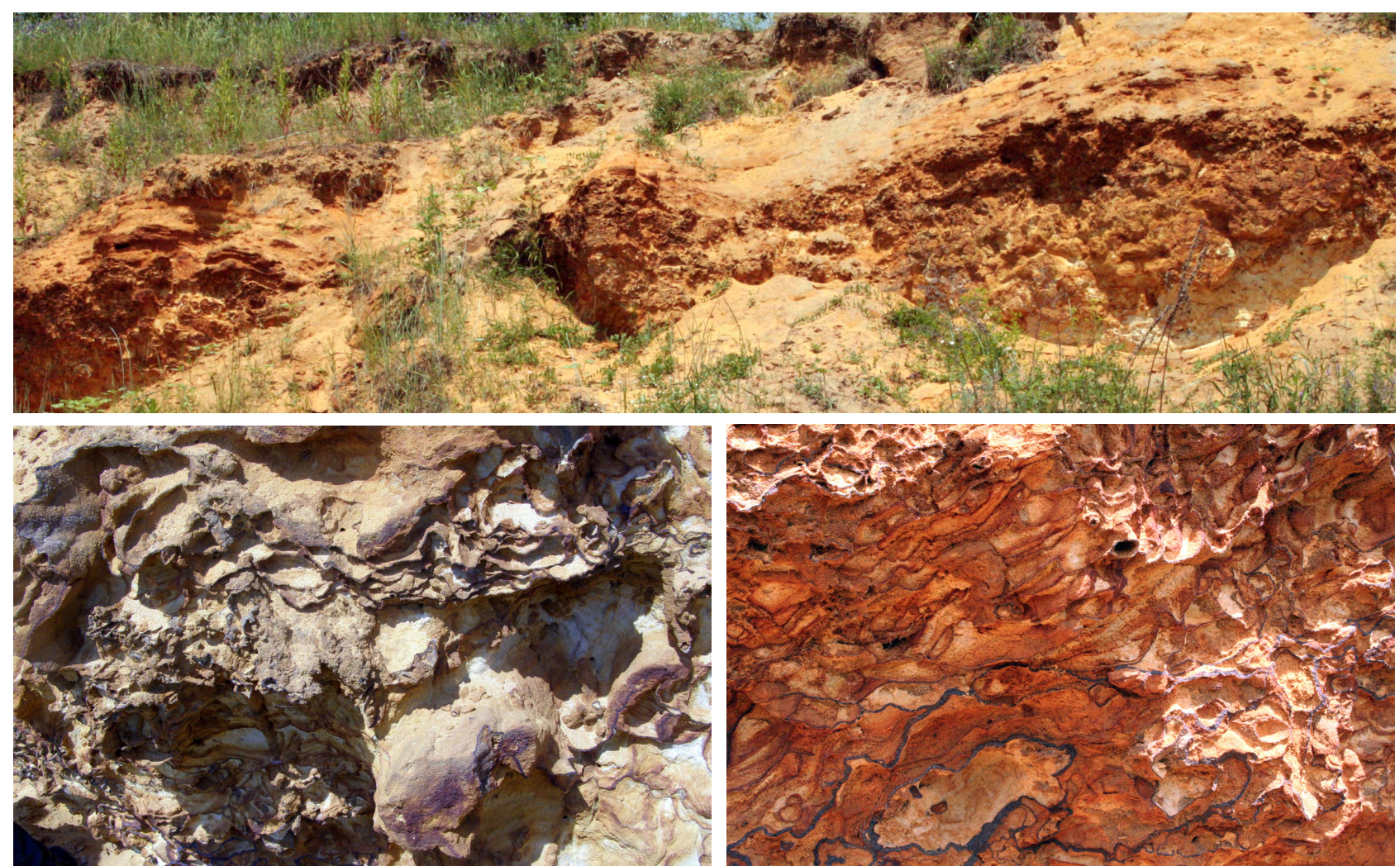

Fig. 14 Siliceous-ferrugenous rocks (ferricretes) in the upper part of the valley of the Psel river in Sumy Oblast 

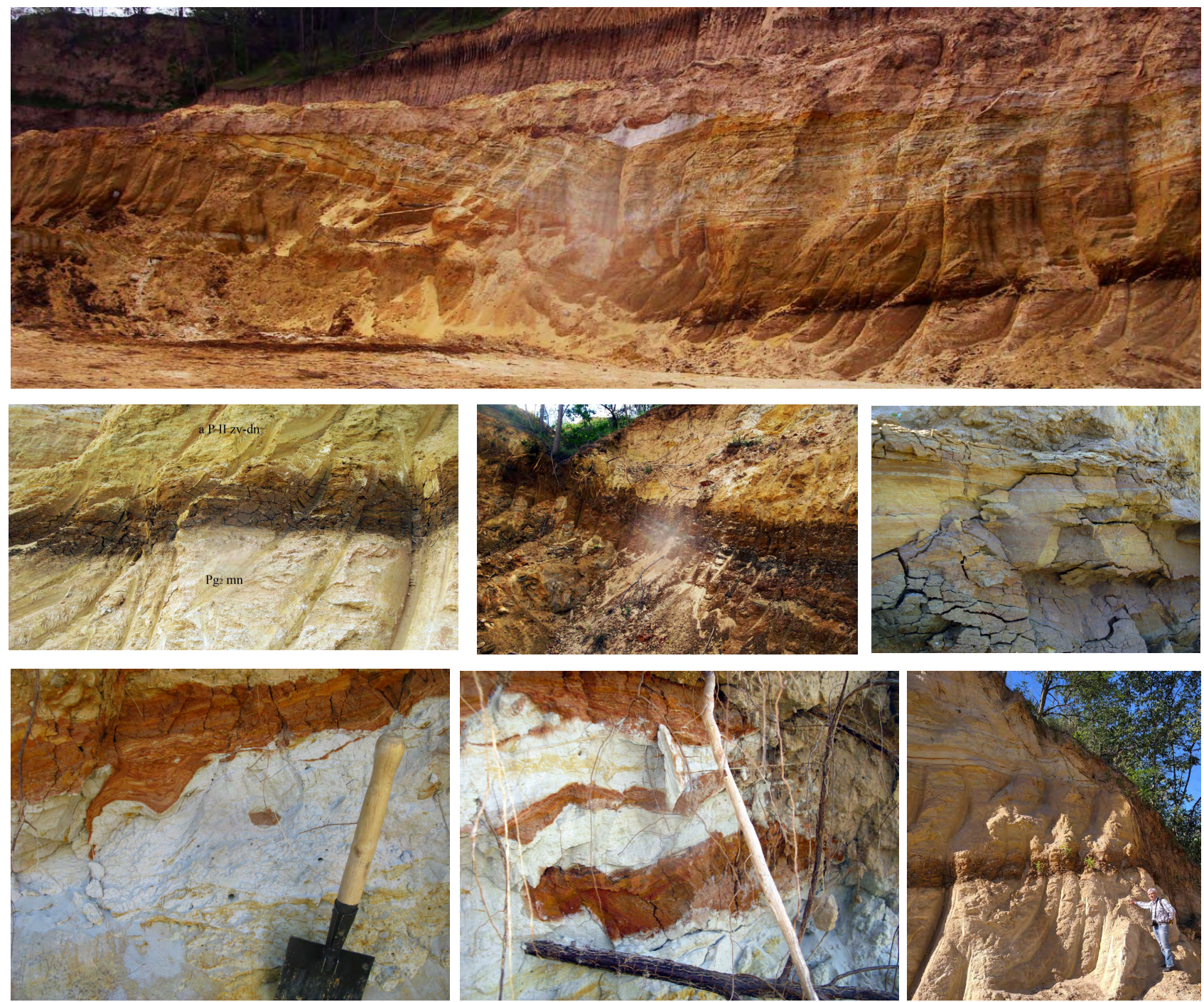

Fig. 15 Red-brown, ochre-brown and dark-green clays in the foot of the fifth terrace $200 \mathrm{~m}$ away to the north-east, in a higher ridge of the Quarry, and therefore on higher hypsometric level ( $+68 \mathrm{~m}$, i.e. $10 \mathrm{~m}$ higher), there is an exposed fragment of geological section ranging from the Tilihulsky loess horizon to the Kryvozhanivsky fossil soil (top-down).

additional surveys. Clays are non-homogenous. In the places where they are overlapped by detritus-carbonate rocks of the Mandrykivski Layers of the Upper Eocene, there are reddish-brown, viscous, plastic clays, quite dense in dry state, with glossy surfaces of colloid coating, thin- average platy texture, with fineshell hydromicas on the surfaces of the jointing, with wells and scattered fine-average grained sand, varying from thin- to large-banded, with small point-like carbonate inclusions and dendrites of manganese oxides. If we assume a marine origin of these clays, they are underwater weathering crust (terra rossa) formed in the processes of halmyrolysis or are the product of dissolution of carbonate silt enriched with detritus of mollusks, corals and other inhabitants of the warm Mandrykivske Sea. Further south, clays are embedded on rocks of the Precambrian basement and differ by their greener colour, with characteristic alternation of red-brown, blue and ochre clays, being more micaceous, often containing a large amount of sand-gravel 114 material, deformed, because often contour and thus replicate the shape of large boulders of granites, the space between which they fill (Fig. 11). Clays often contain large boulders of granites, plagiogranites and conglomerates, both significantly weathered an solid, unaltered, up to $1.5 \mathrm{~m}$ in size. Thickness of clays ranges $0.7 \mathrm{~m}$ above the Mandrykivski Layers to $6 \mathrm{~m}$ on the rocks of the crystalline basement.

1. vdPItl Tilihulsky loess climatolite. Loam of grey-pale yellow, average, loess-like, consolidated, macroporous, of prismatic structure, loose, with carbonate micelles, with small amount point-like inclusions of manganese oxides, with singular molehills. Thickness is $1.8 \mathrm{~m}$.

2. ePI lb Lubensky fossil soil. Loam is brownishbrown with reddish tone, slightly sandy, of prismatic structure, with singular small carbonate concretions, notably more abundant in the foot of the layer. Thickness is $1.0 \mathrm{~m}$.

3. vdP I sl Sulsky loess horizon (cryoturbate). 

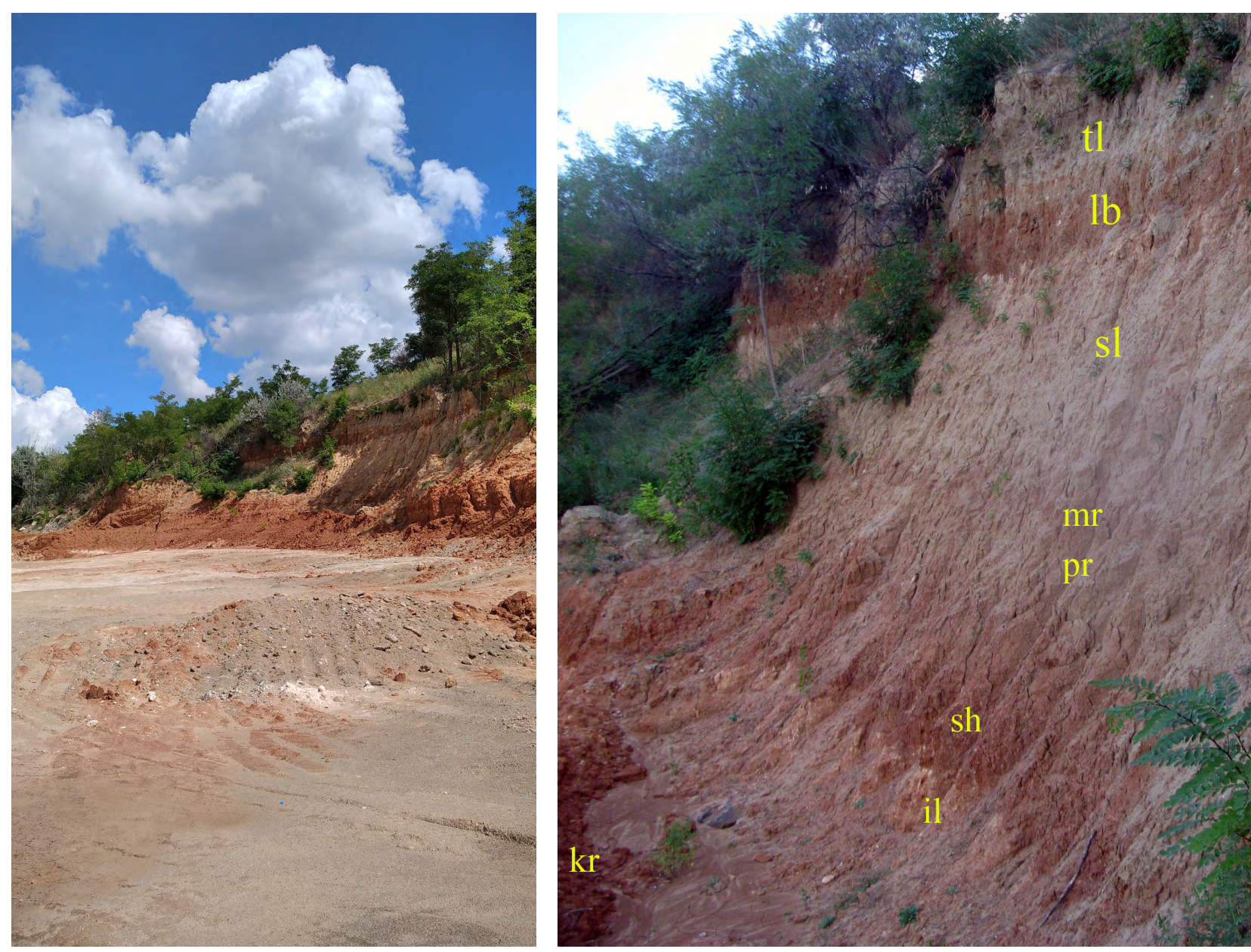

Fig. 16 Section of subaerial deposits of the lower Pleistocene link in the north-east part of the Quarry

Loam is grey-pale yellow to pale yellow-yellow, average, loess-like, with no sand, with many carbonate concretions of up to $15 \mathrm{~cm}$. The upper boundary is uneven, with inflow patter. Thickness is $2 \mathrm{~m}$. (Fig. 16).

4. ePI mr Martonovsky fossil soil. Loam is brown-red-brownish, heavy (heavy loam), dense, of prismatic structure, loose, large-aleuritic structure, with clearly seen illuvial horizon of varying thickness ( 0.1 to $0.5 \mathrm{~m})$. The lower boundary is distinct, highly uneven with seepages. Thickness is $0.9 \mathrm{~m}$.

5. vdPIpr Pryazov loess horizon. Loam is greypale yellow, heavy, with no sand, dense, with abundant particles of small carbonate concretions, with high number of thin layers of dendrites of manganese oxides on the surfaces, of prismatic structure, largealeuritic. Thickness is $1.1 \mathrm{~m}$.

6. ePIsh Shyrokynsky fossil soil. Loam is dark red-brown, darker in the middle part of the layer, highly carbonate, with heavy loam (close to coarsedispersed clay), non-homogenous, in the lower part of the layer there is a large amount of carbonate material varying in size several millimeters to $15 \mathrm{~cm}$. Clearly noticeable illuvial horizon which with inflows is unevenly embedded on clays of the Illichivsky climatolite, Thickness is $1.3 \mathrm{~m}$.
7. 1,vd EII il Illichivsky climatolite. Clay is brown-grey, non-homogenous, with signs of hydromorphism and soil formation, pile-boulder structure, with shimmering surfaces of colloid coating, with large amount of dense carbonate concretions. The upper boundary is indistinct, and very uneven, the lower one is more notable and distinct. Thickness is $0.5-0.7 \mathrm{~m}$

8. e EII kr Clay is bright red-brown, largelydispersed, consolidated, slightly sandy, with large amount of consolidated and loose carbonate concretions which often form vertical column-like forms with dendrites of manganese hydroxides. Thickness is $4 \mathrm{~m}$. Lower down, large granites are embedded.

West of the described outcrop, there is a fragment of section, the structure of which is not similar to the plots located nearby. Despite the fact that the section looks natural, it is hard to explain it logically (Fig. 17). If it was a shift of the block with another structure, than how can one explain the signs of conjunction of different regions, which are not seen? In that case we would have to solve the problem of unnoticeable signs of conjunction of various regions. Perhaps, the causes were neotectonics, or glaciodislocation of frozen blocks in the Dniprovsky period. It has to be 

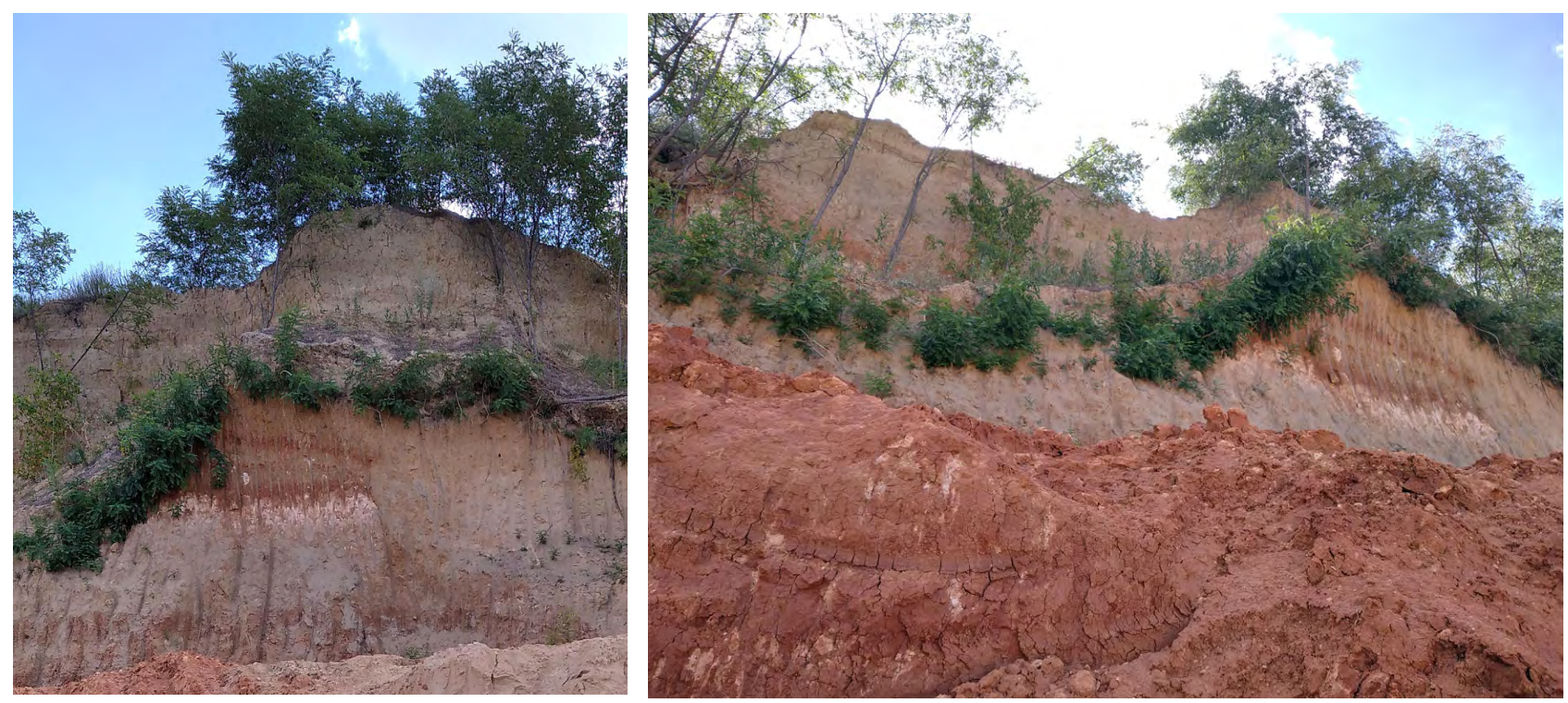

Fig. 17. Fragment of the structure of Quaternary deposits with signs of disorder of initial embedding

noted that the relief there is notably different. The layers are inclined $18^{\circ}$, while being embedded horizontally in the first described fragment. The question remains open to discussion.

Higher and north of the main section (in Fig. 4), there is a fragment of ridge which gives us a great opportunity to see the Upper Pleistocene part of subaerial deposits of the Quaternary system (Fig. 18).

1. vdPIII pč Prychornomorsky climatolite, Loam is yellow-pale yellow, light, loess-like, macroporous, calcareous, fine-aleuritic, of shell-shaped structure, humus in the roof, with uneven gradual boundary. Thickness is $1.1 \mathrm{~m}$.

2. ePIII df Dofinivsky fossil soil. Loam is light brown, light, homogenous, highly calcareous, loose, fine-aleuritic, of prismatic structure, with small car- bonate concretions in the lower part of the layer. The boundary are distinct, even Thickness is $1.2 \mathrm{~m}$.

3. vdPIII bg Buzky loess climatolite. Loam is light-pale yellow, loess-like, loose, macroporous, homogenous, slightly consolidated, of prismatic structure, with a small number of thin coatings of manganese oxides. Thickness is $2.5 \mathrm{~m}$.

4. ePIII vt Vytachivsky fossil soil. Loam is brownish-brown with reddish tone, light, of prismatic structure, in the lower part of the layer has a clearly seen illuvial horizon, lightened, with small carbonate concretions.

Lower down, there is the Udaisky loess, described above, see Fig. 3.

However, the most exotic and non-exposed secrets of the Rybalsky Quarry are the outcrops of the



Fig. 18 Section of subaerial deposits of the Upper link of the Pleistocene 

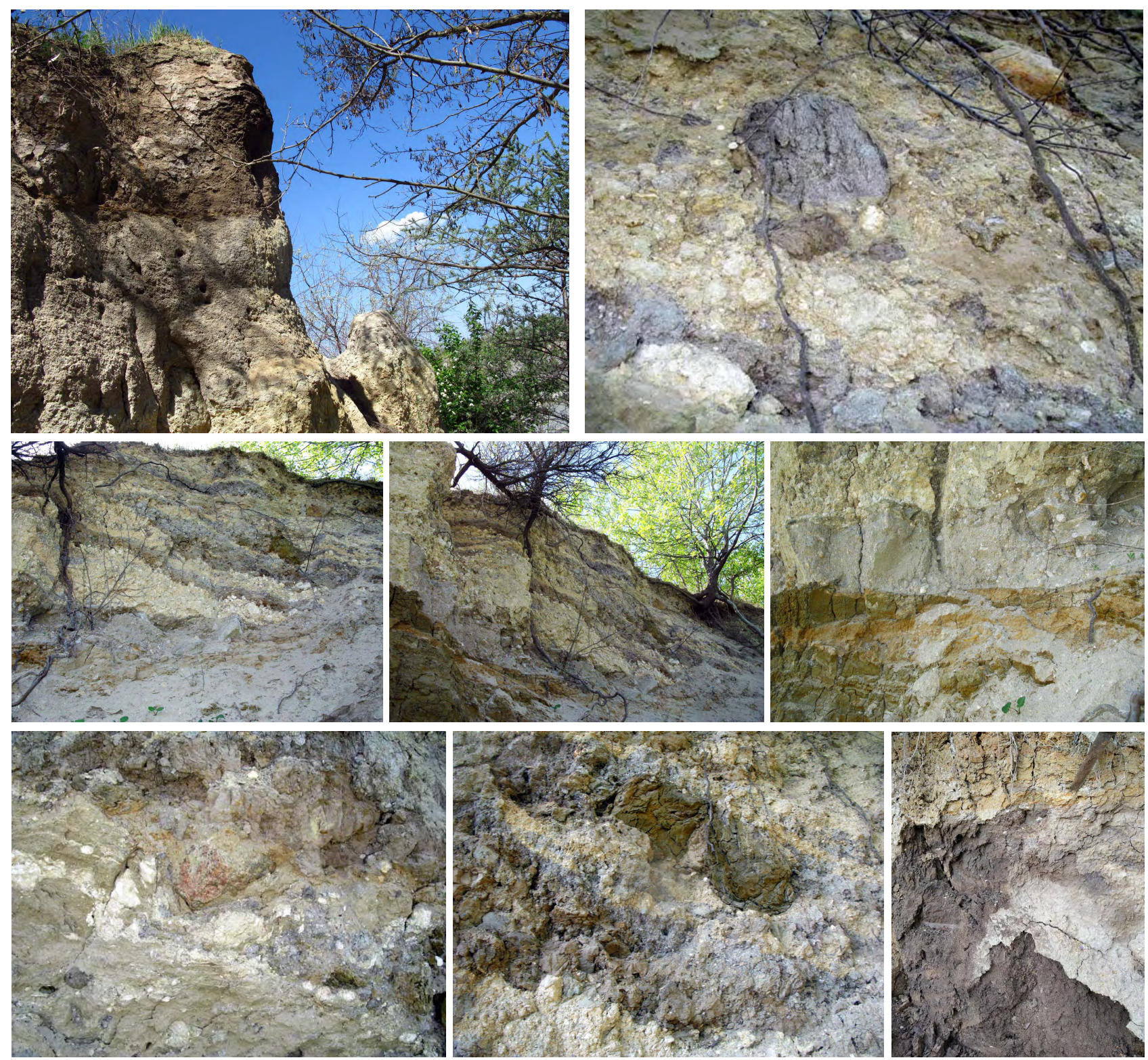

Fig. 19. Section of the "Mandrykivski" Layers or whim of lithogenesis and sedimentogenesis in the outcrop near the spring

Mandrykivski Layers in the north-west part of the Quarry near the well-known source, the lithological - facies composition of which has always encouraged researchers to provide it with status of re-deposited. Only in the study by Berezovsky A. A. and Demianova V. V. (Berezovsky, 2014), for the first time was this "mixtite" - it is hard to call it otherwise - described, being considered as a facies of the Mandrykivske Sea. These outcrops definitely need to be studied and discussed further, which is beyond the scope of this publication. However, the importance of the question and the necessity to solve it demands illustrative material of this section, which I leave with no comments.

\section{Conclusions.}

Many articles have focused on the geology of the Rybalsky Quarry, although it continues to surprise us with new discoveries. The main attraction of the Quar- ry is still the Mandrykivski Layers with unique fossil fauna of the Upper Eocene. However, in 2019, for the first time in over 50 years, a new fragment of the layers was exposed, which expands the possibilities of collection and study of the fossil remains of one of Europe 's best localities of the Priabonian stage deposits. Moreover, for the first time the upper boundary of the Mandrykivski Layers, which was earlier inaccessible, was exposed. Extremely informative is the section of subaerial and subaqueous deposits of the Quaternary system, represented in the Quarry by all links and 18 climatolites ranging from contemporary soil to the Kryzhanovsky horizon. In 2019, for the first time, in all the thickness, the 5 above-floodplain terrace (Hadzhybeiska) was exposed. Its roof was found to have clear signs of activity of fluvioglacial currents in the period of the Dniprovske glaciations. In the lower ridges of the Quarry, there is seen the complex evolu- 
tion of composition of Precambrian crystalline basement due to numerous folded deformations and multiphase nature of development of various components of the complex. Palingenic and injected metasomatic migmatites are widely distributed with a great diversity of texture types and numerous relic fragments of supracrystalline substrate. Distinct signs of influence of the Dniprovske glaciation on the upper part of the Mandrykivski Layers were observed in the south part of the Quarry, where the structure of the section was deformed to such an extent that determining the genesis of deposits, lithological-facies peculiarities, paleogeography and the conditions of sedimentogenesis need additional special surveys. As earlier, the relevant question is still the protection of the territory of the Quarry with the outcrops of the Mandrykivski Layers and best fragments of the Quaternary deposits with the purpose of creation of geological relic (geosites) of nature of national significance (Bezvynniy et al, 2011).

\section{References}

Amitrov, O. V., 1986. Istorija gastropod paleogenovyh morej zapada Evrazii. [History of gastropods of the Paleogene seas of the west of Eurasia]. Moscow, 20-37. (In Russian).

Amitrov, O. V., 1987. Paleogenovye morja Ukrainy, kak svjazujushhee zveno mezhdu morjami severa Zapadnoj Evropy i juga SSSR. [Paleogene seas of Ukraine as a link between the seas of the north of Western Europe and the south of the USSR]. Biostratigraphy, paleontology of the sedimentary cover of Ukraine. Collection of scientific papers, Kiev, Naukova Dumka, 148-150. (In Russian).

Amitrov, O.V., 1996. Scissurellids (Gastropoda, Scissurellidae) from the Upper Eocene of Ukraine. 5: 93-104.

Barg, I.M., Manyuk, V.V., 2004. Dejaki zauvazhennja do stati A.A. Petrenko „Kinceva morena ta stratygrafichne polozhennja mandrykivs'kyh shariv." [Some remarks on the article AA Petrenko «The final moraine and the stratigraphic position of the Mandryk layers.»] Problems of Phanerozoic stratigraphy. Collection of scientific works of IGS, Kyiv, 260-261. (In Ukrainian).

Bezvynniy, V.P., Bobrov, O.B., Bryanskiy, V.P., Vashhenko, V.A., Volnenko, S.O., Manyuk, V.V.... Shevtsova L.F., 2011. Geologichni pam'jatky Ukrai'ny. [Geosites of Ukraine.] In 4 volumes, Ukr. and English languages, Kyiv, vol. IV, 280 p.

Berezovsky, A.A., 1994. O nahodke tipichno verhnejeocenovyh molljuskov v srednejeocenovyh otlozhenijah Juzhnogo sklona Ukrainskogo shhita. [About the find of typical Upper Eocene mollusks in the
Middle Eocene deposits of the southern slope of the Ukrainian Shield.] Stratigraphic and paleontological researches in Ukraine. Kiev, 53-54. (In Russian).

Berezovsky, A.A., 2010. Bival'vii srednego i verhnego jeocena platformennoj Ukrainy: taksonomicheskaja revizija, jevoljucija, paleogeografija i paleojekologija. [Bivalvia of the Middle and Upper Eocene of platform Ukraine: taxonomic revision, evolution, paleogeography and paleoecology]. (Doctoral dissertation: 04.00.09). Kryvyi Rih, 275-308. (In Russian).

Berezovsky, A.A., Demjanov, V.V., 2014. Novye dannye o stroenii verhnejeocenovoj tolshhi Rybal'skogo kar'era g. Dnepropetrovsk. [New data on the structure of the Upper Eocene strata of the Rybalsky Quarry in Dnepropetrovsk.] Materials of the International Scientific and Technological Conference «Steel development of industry and suspension». Kriviy Rig, KNU, 38 - 41. (In Russian).

Berezovsky, A. A., 2015. Upper Eocene bivalves from Dnepropetrovsk, Ukraine: Nuculida and Arcida. Paleontological Journal volume 49, pages987-1099(2015). https://doi.org/10.1134/ s0031030115090014

Bratishko, A.V., 2009. Otolity ryb z mandrykivs'kyh verstv (pryabon) Dnipropetrovs'ka. [Otoliths of fish from Mandrykivka strata (priabon) of Dnipropetrovsk.] Paleontol. zb., 41, 76-85. (In Ukrainian).

Cehovskyi, Ju. G., Bogatyrev, B. A., Zhukov, V. V., 2019. Litogenez na peneplenizirovannoj platformennoj sushe Kazahstana i Sibiri v pogranichnuju melpaleogenovuju epohu. [Lithogenesis on the peneplained platform land of Kazakhstan and Siberia at the boundaryof the Cretaceous-Paleogene epoch]. Litosphere, V. 19, 1, 5-29. doi: 10.24930/ 1681-9004-2019-19-1-5-29

Chekunov, A.V., Veselov, A.A., Gilkman, A.I., 1976. Geologicheskoe stroenie i istorija razvitija Prichernomorskogo progiba. [Geological structure and history of the development of the Black Sea trough]. Kiev, Nauk. Dumka.

Domger, V.A., 1902. Geologicheskie issledovanija v Juzhnoj Rossii v 1881-1884 godah. [Geological research in southern Russia in 1881-1884]. Proceedings of the Geological Committee, v. XX, 1, 187p. (In Russian).

Fehse, Dirk, 2011. Contributions to the knowledge of the Pediculariidae (Mollusca, Gastropoda, Cypraeoidea). On the occurrence of the genus Eotrivia Schilder, 1924 in the Ukraine Eocene, with the description of a new species. Cainozoic Research, Berlin, 8(1-2), 29-34.

Gozhik, P., 2013. Do pitannja vivchennja rozrizu Roksolana. Lesovij pokriv Pivnichnogo Prichornomor'ja. [On the question of studying the section of Roxolana. Forest cover of the Northern Black Sea Coast]. Collection of scientific works (for the XVIII Ukrainian-Polish seminar. Roksolany, 
Ukraine, September 8-13, 2013), 17-33. (In Ukrainian).

Iekel, I., 1895. Nizhnetretichnye seljahii iz Juzhnoj Rossii. [Lower Tertiary Selahia from Southern Russia]. W. Geol. Committee. V. 9, 4, 35. (In Russian).

Jarceva, M.V., 1960. Nummulity paleogenovyh depressij Ukrainskogo kristallicheskogo masiva. [Nummulites of Paleogene depressions of the Ukrainian Crystalline Massif]. Paleogene sediments of the south of the European part of the USSR. Moscow, USSR Academy of Sciences. 165-172 (In Russian).

Kaptarenko-Cheronousova, O.K., 1941. O rasprostranenii mikrofauny $\mathrm{v}$ paleogene zapadnoj i central'noj chastej Dneprovsko-Doneckoj vpadiny. [On the distribution of microfauna in the Paleogene of the western and central parts of the Dnieper-Donetsk depression]. Institute of Geological Sciences of the Academy of Sciences of the Ukrainian SSR, materials on the oil and gas content of the Dnieper-Donetsk depression, Kiev, 121-138. (In Russian).

Kaptarenko-Cheronousova, O.K., 1946. Pro facial'ni zminy kyi'vs'kogo mergelju. [On facial changes in Kyiv marl. Geol]. Journal, vol. VIII, 4, 228258. (In Ukrainian).

Kaptarenko-Cheronousova, O.K., 1949. Novye dannye po geologii paleogena USSR. [New data on the geology of the Paleogene of the Ukrainian SSR]. Kiev, 194-200. (In Russian).

Karlov, N.N., 1950. Morskoe dno v rusle Dnepra (Novoe mestonahozhdenie bogatoj oligocenovoj fauny $\mathrm{v}$ Dnepropetrovske). [Seabed in the channel of the Dnieper (New location of the rich Oligocene fauna in Dnipropetrovsk)]. Nature, 2, 54-55. (In Russian).

Klyushnikov, M.N., 1950. O polozhenii tak nazyvaemyh mandrykovskih sloev. [On the position of the so-called Mandrykov layers]. Scientists notes of Kiev State University, ser. geol., 3, 83-90. (In Russian).

Klyushnikov, M.N., 1953. Nizhnetritetichnye otlozhenija platformennoj chasti Ukrainskoj SSR. [Lower Tertiary deposits of the platform part of the Ukrainian SSR]. Kiev, AS Ukrainian SSR. (In Russian).

Klyushnikov, M.N., 1958. Stratigrafija i fauna nizhnetritichnyh otlozhenij Ukrainy. [Stratigraphy and fauna of the Lower Tertiary deposits of Ukraine. Kiev, Publishing house of the Academy of Sciences of the Ukrainian SSR, $438 \mathrm{p}$.

Konenkova, I.D., Bogdanovich, E.M., Koralova, V.V., Manyuk, V.V., 1995. Paleontologicheskaja harakteristika verhnejeocenovyh otlozhenij Srednego Pridneprov'ja. [Paleontological characteristics of the Upper Eocene deposits of the Middle Dnieper region]. Depon. In DNTB. Ukraine, 1950, UK. 95, $18 \mathrm{p}$.

Kosmachev,V.G., Kosmacheva, M.V., 2018. Chetvertynnyj vulkanichnyj popil Harkivshhyny. [Quater- nary volcanic ash of Kharkiv region]. Bulletin of KhNU named after V.N. Karazna, series „Geology, geography, ecology“", V. 49, 70 - 82. Doi: https://doi.org/10.26565/2410-7360-2018-49-06

Krutzsch W. et Lotsch D., 1957. Zur stratigraphischen Stellung der Latdorfstufe in Paläogen. Geologie 6: 476-301.

Manyuk, V.V., 1998. Geologichni pam'jatky pryrody Dnipropetrovshhyny. [Geological natural monuments (geosites) of Dnipropetrovsk region]. Dnipropetrovsk, Boristen, 2 (80), 2-4.

Manyuk, V.V., 1999a. Zberegty skarby geologichnoi spadshhyny Dnipropetrovshhyny. [Preserve the treasures of the geological heritage of Dnipropetrovsk region]. magazine. "Sacred Work", 3, Dnipropetrovsk, 19-25.

Manyuk, V.V., 1999b. Geologichna spadshhyna Dnipropetrovshhyny. [Geological heritage of Dnipropetrovsk region]. Coll. „Actual problems of geology, geography and ecology. Dnipropetrovsk, Navch. knyga, 3, 81-90.

Manyuk, V.V., 2001a. Osoblyvosti geologichnoi‘ budovy Rybal's'kogo kar'jeru. [Features of the geological structure of the Rybalskyi quarry]. Scientific Bulletin of NSAU. Dnipropetrovsk, 62-63. (In Ukrainian).

Manyuk, V.V., 2001b. Turystychni aspekty vykorystannja geologichnyh pam'jatok pryrody. [Tourist aspects of the use of geological natural monuments (geosites]. Coll. „Sustainable development of tourism on the Black Sea coast.“ Odessa, 50-59.

Manyuk, V.V.2001c. Quaternary geology ofDnepropetrovsk region. Volum of Abstracts "The Ukraine Quaternary Explored: the Middle and Upper Pleystocene of the Middle Dnieper Area and its importance for the East-West correlation." Kyiv, 54.

Manyuk, V.V. 2002a. Pro tajemnyci pryrody, jaki nam vidkryv Rybal's'kyj kar'jer. [About the secrets of nature, which were revealed to us by the Rybalskyi Quarry]. Inform.- journalistic. bull. «Sacred Work.» 1 (5), 15-17.

Manyuk. V., 2002b Geological Heritage of the Dnipropetrovsk region. Natural and Cultural landscapes: the geological foundation. Dublin, Ireland, 25-26.

Manyuk, V., 2002c. Geologichni vidkryttja Vasylja Zujeva ta Valeriana Domgera na Katerynoslavshhyni. [Geological discoveries of Vasyl Zuev and Valerian Domger in the Ekaterinoslav region]. Humanitarian Journal, REC NGAU, 2 (14), Dnipropetrovsk, 107-108.

Manyuk, V., 2002d. Geological heritage of a southern part of Ukraine.//Natural and Cultural landscapes. Proceedings of a conference, Dublin Castle, 9398. Edited by Matthew Parkes, 2004.

Manyuk, V., 2003a. Paleontologycheskye pamjatnyky pryrody Srednego Prydneprov'ja. [Paleontological natural monuments (geosites) of the Middle Dnieper region]. Paleontology and nature man- 
agement - Abstracts of reports. XLIX session paleont. society, Moscow-Saint Petersburg, 127-128.

Manyuk, V., 2003b. Dejaki problemni pytannja biostratygrafii' pizn'ogo eocenu Seredn'ogo Prydniprov'ja. [Some problematic issues of the biostratigraphy of the late Eocene of the Middle Dnieper]. Theoretical and applied aspects of modern biostratigraphy of the Phanerozoic of Ukraine. Kyiv, 132-135.

Manyuk, V., 2004. Naukove pidg'runtja ta praktychnyj dosvid $\mathrm{v}$ doslidzhenni stratygrafichnyh ta paleontologichnyh pam'jatok pryrody pivdennyh i shidnyh regioniv Ukrai'ny. [Scientific basis and practical experience in the study of stratigraphic and paleontological monuments of nature of the southern and eastern regions of Ukraine]. Problems of Phanerozoic stratigraphy.-Collection of scientific works of IGS, Kyiv, 253-259.

Manyuk, V., 2012. Mandrykivs'ki verstvy - unikal'na paleontologichna pam'jatka Jevropy.//Paleontologichni doslidzhennja $\mathrm{v}$ udoskonalenni stratygrafichnyh shem fanerozojs'kyh vidkladiv. [Mandrykivka strata - a unique paleontological monument of Europe]. Paleontological research in improving the stratigraphic schemes of Phanerozoic sediments: Mater. XXXIV session of the Paleontological Society of the National Academy of Sciences of Ukraine. (Dnipropetrovsk, May 28-31, 2012). Kyiv, 80 - 82.

Manyuk, V., 2014. Chetvertynni vidklady u Rybal's'komu kar'jeri m. Dnipropetrovs'ka. [Quaternary deposits in the Rybalsky Quarry of Dnipropetrovsk]. Bulletin of DNU, series: Geology, Geography. Dnepropetrovsk, Vol. 22, 16, 3 / 2, 107 - 111. Doi: https://doi.org/10.15421/111412

Manyuk, V., 2017. Pro zminennja polozhennja pivdennoi' granyci Dniprovs'kogo (rys'kogo) zledeninnja. [On changing the position of the southern border of the Dnieper (Riss) glaciation]. Bulletin of Dnipropetrovsk University. Series: Geology, Geography. Dnepropetrovsk, 25 (2), 21, 99-110. Doi: https://doi.org/10.15421/111724

Martini, Erland, Ritzkovski, Siegfried. 1970. Stratigraphische Stellung der ober-eozänen Sande von Mandrikovka (Ukraine) und Parallesierungs. Möglichkeiten mit Hilfe des Fossilen Nannoplanktons. Newsl. Stratigr.

Matviishyna, Zh.M., Gerasymenko, N.P., Perederii, V.I., Bragin, A.M., Ivchenko, A.S.,Nagirnyi, V.M., Parhomenko,A.P., 2010. Prostorovochasova koreljacija paleogeografichnyh umov chetvertynnogo periodu na terytorii' Ukrai'ny. [Spatial-temporal correlation of paleogeographic conditions of the Quaternary period on the territory of Ukraine]. Kyiv, Nauk. dumka, NAS of Ukraine, 200p.

Muller, A., Rozenberg, O. 2002. Otolithen aus den Mandrikovka- Schichten (Priabonium) von Dhepropetrovsk (Ukraine). Leipzig, 18 p.
Müller, A., \& Rozenberg, A. (2003). Teleostei-Otolithen aus den Mandrikovka-Schichten (Priabonium) von Dnepropetrovsk (Ukraine). Paläontologische Zeitschrift, 77(2), 361-387. Doi: https://doi. org/10.1007/bf03006948

Nesterenko, P. G., 1960. Paleogenovye otlozhenija okrestnostej g. Dnepropetrovska i stratigraficheskoe polozhenie mandrikovskih sloev. [Paleogene deposits of the environs of Dnepropetrovsk and the stratigraphic position of the Mandrikian layers.] Paleogene deposits of the south of the European part of the USSR. Moscow, Publishing house of AS USSR, 136-142.

Nosovskyi, M.F., Konenkova, I.D., Barg, I.M., Bogdanovich, E.M., 1978. Novye mestonahozhdenija mandrikovskih sloev v rajone Dnepropetrovska i ih paleontologicheskaja harakteristika. [New localities of the Mandrikovskian layers in the region of Dnepropetrovsk and their paleontological characteristics]. Stratigraphy of the Cenozoic of the Black Sea region and Crimea. Dnepropetrovsk, DSU, 2, 40 - 48.

Petrenko, A.A., 2003. Kinceva morena ta stratygrafichne polozhennja mandrykivs'kyh shariv. [The final moraine and the stratigraphic position of the Mandrykian layers]. Mineral Resources of Ukraine. 4, 4-6.

Rozenberg, A., 2001. Vozmozhnosti ispol'zovanija otolitov kostnyh ryb v paleontologii s primeneniem nekotoryh iskopaemyh kompleksov iz kajnozoja juga Ukrainy. [Possibilities of using otoliths of bony fish in paleontology with the use of some fossil complexes from the Cenozoic of the south of Ukraine]. Paleontological substantiation of stratons by the Phanerozoic of Ukraine. Kyiv, 56 - 60.

Sokolov, N.A., 1905. Fauna molljuskov Mandrikovki. [Fauna of Mandrikovka mollusks]. Proceedings of Geolkom, New series, 18, 82 p.

Stefanskyi, V. L., 1987. K izucheniju fauny molljuskov mandrykovskih sloev Chaplinskogo granitnogo kar'era (g. Dnepropetrovsk). [On the study of the mollusk fauna of the Mandrykovka layers of the Chaplinsky granite quarry (Dnepropetrovsk)]. Biostratigraphy and paleontology of the sedimentary cover of Ukraine. Kiev, Naukova Dumka, 160-162.

Stefanskyi, V. L., 1992. Dvustvorchastye molljuski pozdnego jeocena Severnogo Prichornomor'ja i jugo-vostochnoj chasti Ukrainskogo shhita, ih stratigraficheskoe znachenie. [Bivalve molluscs of the Late Eocene of the Northern Black Sea region and the southeastern part of the Ukrainian Shield, their stratigraphic significance]. Autoref. Cand. geol.-min. Sciences, Kiev: IGS NAS of Ukraine, $21 \mathrm{p}$.

Stefanskyi, V. L., 2013a. O tehnogennyh i prirodnyh narushenijah mandrykovskih sloev Rybalskogo kar'era (g. Dnepropetrovsk). [Technogenic and 
natural disturbances of the Mandrikian layers of the Rybalskyi Quarry (Dnepropetrovsk)]. Geological and mineralogical newsletter of the Kryvyi Rih National University. 1-2 (29-30), 73-78.

Stefanskyi, V. L., 2013b. K voprosu o korrelacii verhneeocenovyh otlozhenij Srednego Pridneprovia i Severnogo Prichernomoria. [On the question of the correlation of upper Eocene sediments of the Middle Dnieper and Northern Black Sea regions]. Bulletin of Dnipropetrovsk University. Series "Geology. Geography “, 21,3/2, 3-9. Doi: https:// doi.org/10.15421/111303

Stefanskyi, V. L., 2014. Verhn'oeocenovi onkolitovi biogermy Rybal's'kogo kar'jeru (m. Dnipropetrovs'k) jak facial'nyj indykator mandrykivs'kyh verstv. [The Upper Eocene oncolitic bioherms of Rybalsky Quarry (Dnepropetrovsk) as indicator facies Mandrikovka beds]. Bulletin of Dnipropetrovsk University. Series «Geology. Geography, «22, 3/2, 121-144. Doi: https://doi.org/10.15421/111414

Stefanskyi, V. L., 2015a. Tafonomicheskie aspekty issledovanija mandrykovskih sloev verhnego jeocena (g. Dnepropetrovsk, Ukraina). [Taphonomic aspects of the study of the Mandryk layers of the Upper Eocene (Dnepropetrovsk, Ukraine)]. Bulletin of Kharkiv National University, Kharkiv, $1157,58-62$

Stefanskyi, V. L., 2015b. Paleogeograficheskie i litologo-facial'nye osobennosti formirovanija mandrykovskih sloev verhnego jeocena Ukrainy (g. Dnepropetrovsk). [Paleogeographic and lithological-facies features of the formation of the Mandrykian layers of the Upper Eocene of Ukraine (Dnepropetrovsk)]. Bulletin of Dnipropetrovsk University. Series: Geology, Geography. 23 (1), 125-136. Doi: https://doi.org/10.15421/111517
Shirokov, A. Z., Dyssa, F. M., 1972. O vozraste i stratigraficheskom polozhenii mandrikovskih sloev. [On the age and stratigraphic position of the Mandrik beds]. Dnepropetrovsk Mining Institute. $111,40-45$.

Shirokov, A. Z., Veselov, A. O., Stefans'kij, V. L., Petrusha, V.I., 1986. Formuvannja i vik mandrikivs'kih shariv na okolicjah m. Dnipropetrovs'ka. [Formation and age of Mandrykivian strata on the outskirts of Dnepropetrovsk]. Reports of the USSR Academy of Sciences. 2, 25-28.

Udovychenko, M., 2009. Elasmobranhii' mandrykivs'kyh verstv Dnipropetrovs'ka. [Elasmobranchia of the Mandrykivski Layers of Dnipropetrovsk. 1. Squatiniformes, Heterodontiformes, Orectolobiformes, Lamniformes. Paleontological Zbirnik, 41, 27-36.

Udovychenko, M., 2010. Elasmobranhii' mandrykivs'kyh verstv Dnipropetrovs'ka. [Elasmobranchia of the Mandrykivski Layers of Dnipropetrovsk. 2. Carcharhiformes, Rajiformes, Myliobatiformes. Paleontological Zbirnik, 42, 89-96.

Veselov, A. O., 1972. Pro stratygrafichne polozhennja i analogy mandrykivs'kyh verstv u Prychornomors'kij zapadyni. [On the stratigraphic position and analogues of the Mandrykivka strata in the Black Sea basin]. Report of the USSR Academy of Sciences, 6, 490-492. (In Ukrainian).

Veselov, A. A., Golev, B. T., Lyulieva, S. A., Savenko, N.G., Sheremeta, V.G.,1974. Novye dannye o stratigraficheskom polozhenii i vozraste mandrikovskih sloev okrestnostej g. Dnepropetrovska (USSR). [New data on the stratigraphic position and age of the Mandrikovka layers in the vicinity of Dnepropetrovsk (Ukrainian SSR). Dokl. Academy of Sciences of the USSR. V. 217, 5, 1145-1147. (In Russian). 